\title{
Recent developments in 8-aminoquinoline antimalarials
}

\author{
By B. K. Bhat, M. Seth and A. P. Bhaduri* \\ Division of Medicinal Chemistry, Central Drug Research Institute, \\ Lucknow 226001, India
}

* To whom all correspondence should be made. CDRI communication No. 3364

$1 \quad$ Introduction . . . . . . . . . . . . . . . . . . . . . . . 198

1.1 The importance of 8-aminoquinoline derivatives as antimalarials ... 199

1.2 Trends of current research on 8 -aminoquinolines ........... 200

2 Screening strategy, molecular modifications and structure-activity relationship (SAR) in 8-aminoquinoline antimalarials $\ldots \ldots \ldots \ldots 202$

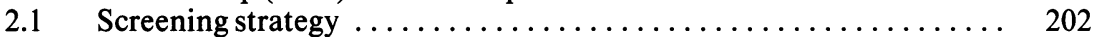

2.11 Primary mouse prophylactic screen $\ldots \ldots \ldots \ldots \ldots \ldots \ldots \ldots \ldots, 202$

2.12 Secondary causal prophylactic screens $\ldots \ldots \ldots \ldots \ldots \ldots \ldots \ldots 202$

2.13 Radical curative test ......................... 204

2.2 Molecular modifications and SAR in 8-aminoquinolines ....... 204

2.21 2-Substituted primaquine analogs .................... 205

2.223 -Substituted primaquine analogs $\ldots \ldots \ldots \ldots \ldots \ldots \ldots \ldots . \ldots . \ldots 206$

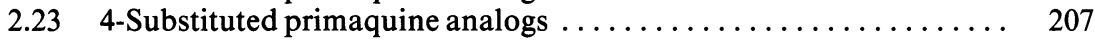

2.245 -Substituted primaquine analogs $\ldots \ldots \ldots \ldots \ldots \ldots \ldots \ldots . \ldots \ldots$

$2.254,5$-Disubstituted primaquine analogs $\ldots \ldots \ldots \ldots \ldots \ldots \ldots \ldots 211$

2.26 The contribution of the quinoline ring towards curative activity .... 213

3 Biochemistry, pharmacokinetics and metabolism of

8 -aminoquinoline antimalarials $\ldots \ldots \ldots \ldots \ldots \ldots \ldots \ldots \ldots, 214$

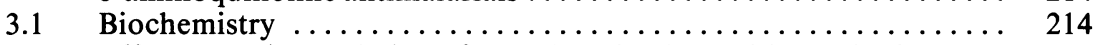

3.11 Effect on aminoacylation of t-RNA and polypeptide synthesis .... 215

3.12 Effect on phospholipid metabolism and lipid biosynthesis ....... 215

3.13 Effect on nucleic acid synthesis, phosphorylation of adenosine and

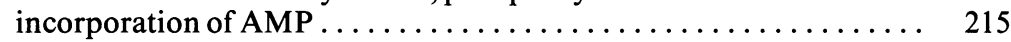

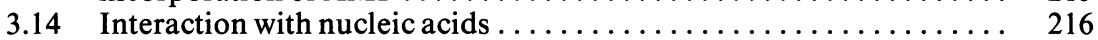

3.15 Effect on energetics of mitochondria $\ldots \ldots \ldots \ldots \ldots \ldots \ldots \ldots \ldots \ldots, 216$

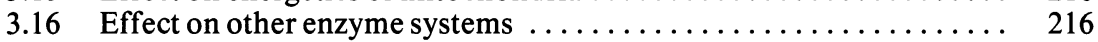

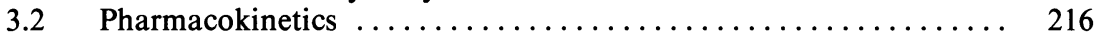

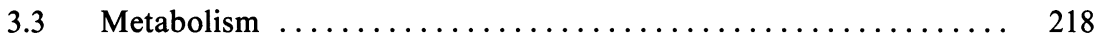

$4 \quad$ Mechanism of action, side effects, toxicity and miscellaneous studies 219

$4.1 \quad$ Mechanism of action ............................ 219

4.2 Side effects of 8 -aminoquinolines $\ldots \ldots \ldots \ldots \ldots \ldots \ldots \ldots \ldots, 220$

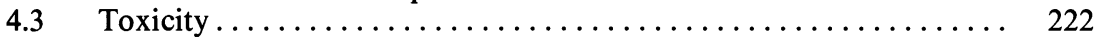

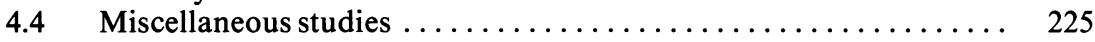

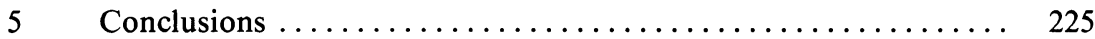

Acknowledgment.............................. 227

References ............................... 227 
Malaria is an old scourge of mankind and mention of the disease is found in ancient writings in India, Egypt and China [1]. The clinical symptoms of this disease were described by Hippocrates 400 years before the Christian era [1]. Human population affected by malaria is alarmingly large in tropical regions although in the past the disease was also prevalent in temperate regions [1]. The respite from this disease after World War II, due to the success in the control of the vector mosquitoes and development of new antimalarials, was, however, short lived and malaria has staged a come back in recent years. Only two decades back WHO had stated 'The clinicians have at their disposal a complete series of effective drugs for the treatment of all stages of this disease' [2] but in 1971 the same organization considered malaria eradication as a difficult problem both technically and politically [3] and commented 'Thus there is no avoiding the conclusion that malaria will be with us for quite sometime. In order to cope more efficiently with this world-wide problem, much more research is required' [4]. It would, therefore, be pertinent to analyse the main causes of this setback. The principal reason is undoubtedly the appearance of drug-resistance in malarial parasites. Resistance to all the currently available drugs is a reality; even the age-old remedy, quinine, has the same limitations as the synthetic drugs. The development of methods for detecting the presence of chloroquine resistance in P. falciparum and the in vitro test, developed by Rieckmann [5, 6], have contributed much towards the chemotherapy of malaria. These methods have also helped in mapping the geographical distribution of drug-resistant strains [7]. Resistance of $P$. falciparum to 4-aminoquinolines has been reported from East Africa, Bangladesh, Burma, China, India, Papua New Guinea, the Philippines, the Solomon Islands and Vanuatu (formerly New Hebrides) in addition to the previously known areas of northern South America and Southeast Asia, though in most cases the phenomenon is restricted to only parts of these areas. This large geographical distribution and the stationing of US forces in malaria endemic regions in the Far East led the US army authorities to take a major interest in the development of oral prophylactic and therapeutic agents [19] that would be effective against drug-resistant $P$. falciparum malaria.

In a massive programme directed towards this objective, over 200000 compounds were screened as blood schizontocidal agents and at least 
ten of these were selected for preclinical or clinical studies [19]. However, the programme was not restricted to $P$. falciparum malaria alone and another objective of the study was the related problem of $P$. vivax malaria [19]. Much of the human suffering and temporary disability, specially in Asia, are due to infections caused by $P$. vivax and in this context it would not be out of place to mention that the pathogenic role of $P$. malariae still remains to be elucidated. Moreover, it is known that epidemics of $P$. vivax malaria can recur after eradication since transmission of the infection may be re-established from subjects with extremely late manifestation because genetic recombination in mosquitoes may again produce phenotypes with early activity [8]. Thus the various problems of malarial infection, other than P. falciparum, may well represent the 'tip of an iceberg' with the crux of the problem still remaining hidden [9].

1.1 The importance of 8-aminoquinoline derivatives as antimalarials

The inability of chloroquine, one of the most active 4-aminoquinoline antimalarials in clinical use, to prevent relapses in patients with $P$. vivax infection was observed in mid-40's. Since in relapsing malaria, the parasites persist at exoerythrocytic sites such as liver parenchymal cells and R. B. C., the need to use tissue schizontocidal agents was obvious [10]. The introduction of combination therapy with pamaquine (III) [11], a derivative of 8 -aminoquinoline and quinine for relapsing malaria was not successful since the combination was found to be too toxic for clinical use. Pentaquine (IV), another candidate 8-aminoquinoline antimalarial tried clinically, in combination with quinine against $P$. vivax infection, could significantly reduce the relapse rate in malaria infected US army personnel [12]. Further attempts to obtain better 8-aminoquinoline antimalarials led to the discovery of primaquine (I) as the least toxic and most effective [13-15]. With the resurgence of malaria, interest in development of less toxic tissue schizontocidal agents was again focussed on 8-aminoquinolines because the<smiles>[R]Nc1cc(OC)cc2cccnc12</smiles>

Important candidate 8-aminoquinoline antimalarials 


$\begin{array}{rll}\text { I: } & \text { Primaquine } & \mathrm{R}=-\mathrm{CH}\left(\mathrm{CH}_{3}\right)-\left(\mathrm{CH}_{2}\right)_{3}-\mathrm{NH}_{2} \\ \text { II: } & \text { Quinocide } & \mathrm{R}=-\left(\mathrm{CH}_{2}\right)_{3}-\mathrm{CH}\left(\mathrm{CH}_{3}\right) \mathrm{NH}_{2} \\ \text { III: Pamaquine } & \mathrm{R}=-\mathrm{CH}\left(\mathrm{CH}_{3}\right)-\left(\mathrm{CH}_{2}\right)_{3}-\mathrm{N}(\mathrm{Et})_{2} \\ \text { IV: Pentaquine } & \mathrm{R}=-\left(\mathrm{CH}_{2}\right)_{5}-\mathrm{NH}-\mathrm{CH}\left(\mathrm{CH}_{3}\right)_{2} \\ \text { V: Isopentaquine } & \mathrm{R}=-\mathrm{CH}\left(\mathrm{CH}_{3}\right)-\left(\mathrm{CH}_{2}\right)_{3}-\mathrm{NH}-\mathrm{CH}\left(\mathrm{CH}_{3}\right)_{2} \\ \text { VI: Plasmocid } & \mathrm{R}=-\left(\mathrm{CH}_{2}\right)_{3}-\mathrm{N}(\mathrm{Et})_{2}\end{array}$

sporontocidal effect [1] of this class of compounds on the parasites in the mosquito was likely to break the infection cycle necessary for the propagation of the plasmodia. 8-aminoquinolines are of interest to medicinal chemists not only because they are effective in the treatment of relapses but also because they are the only group of compounds having well-defined tissue schizontocidal, gametocytocidal and chemoprophylactic activities. Fortunately although there are geographic differences in the sensitivity of persistent tissue stages of vivax malaria to primaquine $[16,17]$, true drug-resistance has not been unequivocally demonstrated. However, the ease with which Arnold et al. [18] were able to induce primaquine resistance experimentally in vivax malaria, emphasizes the need for alternative tissue schizontocides.

\subsection{Trends of current research on 8-aminoquinolines}

Developing an appropriate screening strategy to identify new tissue schizontocides, understanding structure-activity relationship (SAR) in 8-aminoquinolines for carrying out molecular modifications, elucidating the mechanism of biochemical interactions in the host for reducing side effects, studying the fate of the compounds in the biophase and toxicity studies represent the current trends of research on 8-aminoquinolines. A proper appreciation of the present status of this class of antimalarials is possible only when the current research activities are considered against the background of the individual discipline. This concept has been followed in the style and format of this review for acquainting the reader with the recent developments in 8-aminoquinoline antimalarials. 


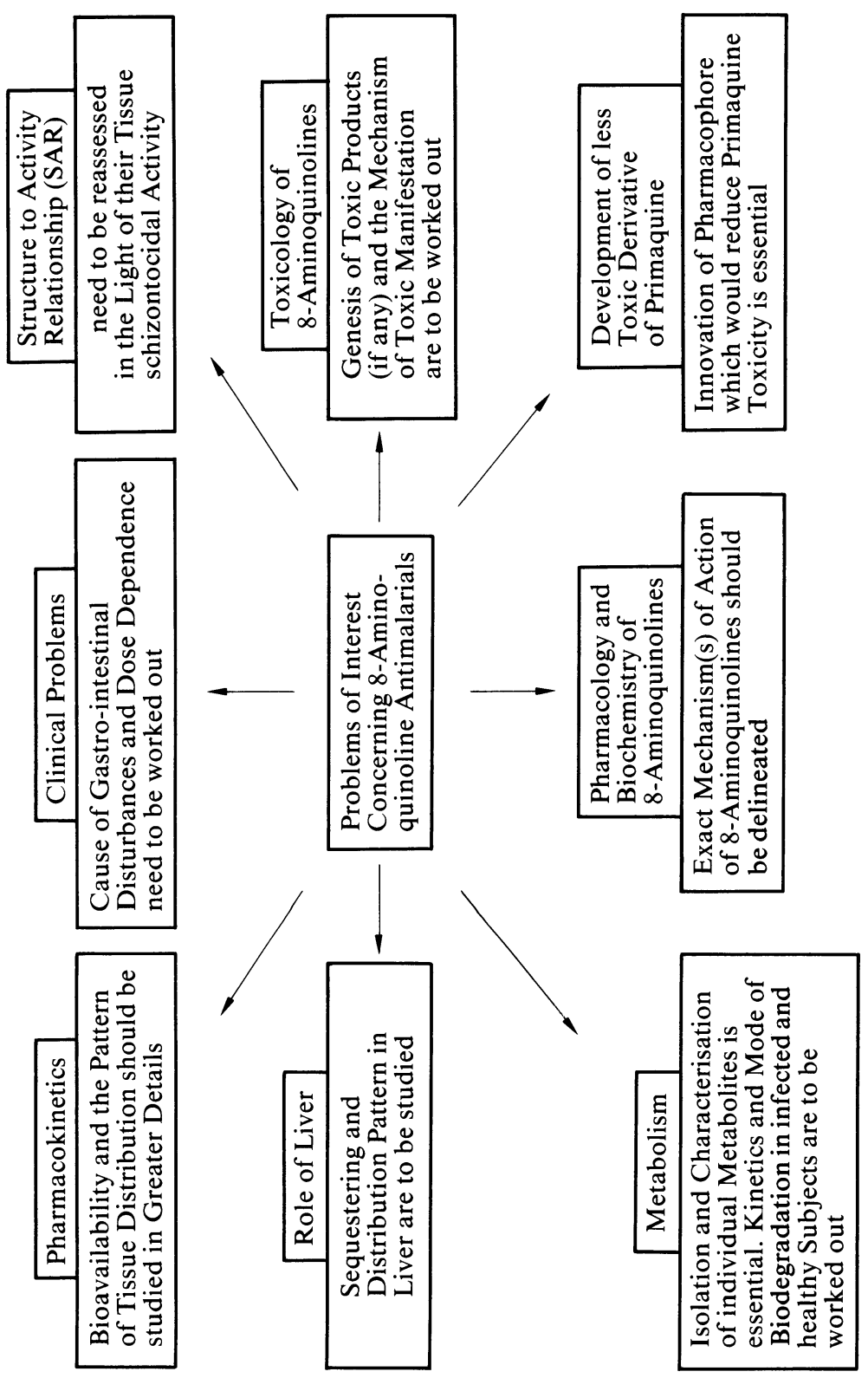


Screening strategy, molecular modifications and structureactivity relationship (SAR) in 8-aminoquinoline antimalarials

\subsection{Screening strategy}

Antimalarial screening of tissue schizontocides consists of a sequence of steps, each of which gives only one piece of information. In developing the screening strategy, studies on malarias of sub-human primates have proved invaluable. There are experimental models of malaria which closely parallel the infection in humans in regard to the biology, pathology and response to antimalarial drugs. Despite the fact that these experimental models are valuable research tools, screening of possible antimalarial compounds for tissue schizontocidal activity, unlike blood schizontocidal screening, is not possible on a large scale due to economic constraints. A screening strategy for new tissue schizontocides was, therefore, considered necessary and the one adopted by WHO appears to be the most suitable. In this procedure a compound has to pass through three stages of testing before it can qualify for clinical trial. These stages are primary causal prophylactic screen in mouse, a pair of secondary causal prophylactic screens and a radical curative test in rhesus monkey. The details are as follows.

\subsection{Primary mouse prophylactic screen [19]}

In this screen, the test compound, in the form of a solution or suspension (by ultrasonication) in a suitable vehicle such as arachis oil, is administered subcutaneously to mice [20]. After 2 hours, $P$. yoelii sporozoites or approximately $10^{6}$ infected donor red cells are given intraperitoneally to the animals. In the untreated infected animals (controls) $99 \%$ mortality is observed, with a mean survival time of 9.8 days. If the test compound, at any given dose, increases the mean survival time in $2 / 5$ test animals to thrice that in the controls, the compound is considered active. Thus, this method provides a rapid screening model for identifying possible antimalarial agents which merit screening for causal prophylactic activity.

\subsection{Secondary causal prophylactic screens}

The causal prophylactic test described by Gregory and Peters [21] uses 
two groups of mice which are inoculated with a suspension of sporozoites via the tail vein on day zero. After 1 hour the test compound is administered. The first group is kept as such while the second group after 48 hours is inoculated intravenously with $10^{7}$ infected erythrocytes. Separate mock-treated controls are used for each group. Thin blood films are examined daily from day 3 to day 14 for presence of parasites and if all are found to be negative on day 14 then the test compound is considered to be a causal prophylactic. If the mathematical analysis of the parasitaemia data gives a value less than 1.0, then the activity is considered to be insignificant $[21,58]$.

A reduced blood parasitaemia in the second group of mice, indicates a residual action longer than the 48 hours duration of the preerythrocytic cycle. A mathematically derived value of less than +0.5 denotes insignificant residual activity. In the case of the compounds showing residual acticity, blood is collected from infected mice 52-53 hours after the initial sporozoite infection and inoculated intraperitoneally into clean animals [22]. The blood films of the new recipients are examined daily upto 14 days and the development of parasitaemia in less than $50 \%$ of animals is indicative of activity against the preerythrocytic tissue infection of the donors [23]. This model is based on the observation that most antimalarial compounds require 3-4 hours to produce irreversible changes in intra-erythrocythic parasites.

Yet another model for causal prophylactic screening, developed by Most and Montouri [24], helps to differentiate between causal prophylactic and suppressive prophylactic activities. The test drug is administered orally or subcutaneously to rats on two consecutive days and on the second day they are incoulated intravenously with either 10000 or 250000 sporozoites of $P$. berghei. After $43-45$ hours the rats receiving a higher inoculum are sacrificed. Their livers are taken out, cut into fine sections, stained and microscopically examined for exoerythrocytic forms. If there is absence or significant reduction of these forms, the compound possesses causal prophylactic activity. The rats receiving a lower inoculum are examined routinely to follow the course of parasitaemia. The absence of parasitaemia, further confirmed by subinoculation into mice, indicates a parasitological cure (suppressive prophylaxis). 


\subsection{Radical curative test [25]}

Schmidt et al's model of persistent tissue stages of $P$. cynomolgi bastianelli malaria in rhesus monkeys is employed. The test compound is given orally to the monkeys for 7 days, beginning 10-12 days after the intravenous incoulation of $0.5-1.5 \times 10^{6}$ sporozoites. This roughly corresponds to 2-4 days after the appearance of parasitaemia. To eliminate interference due to blood forms, chloroquine phosphate in a dose of $5 \mathrm{mg} / \mathrm{kg}$ per day is also given along with the test compound. If no relapse of parasitaemia occurs within 100 days, the compound is considered to have cured the exoerythrocytic infection.

\subsection{Molecular modifications and SAR in 8-aminoquinolines}

Till 1971 the attempts to obtain better 8-aminoquinoline antimalarials were primarily concerned with structural changes in the side chain attached to the amino group at position 8 of the quinoline nucleus. Molecular modifications carried out since then have been directed to the quinoline nucleus, keeping the side chain by and large the same as in primaquine (I).

Salient structural modifications in 8-aminoquinoline antimalarials prior to 1971 (literature references appear in enclosures)<smiles>[R]Nc1cc(OC)cc2cccnc12</smiles>

Description of the side chain (R) attached to the 8-amino group

$-\left(\mathrm{CH}_{2}\right)_{\mathrm{n}-\mathrm{N}(\mathrm{Et})}, \mathrm{n}=2-11$ [26, 27]; $-\mathrm{CH}\left(\mathrm{NEt}_{2}\right)-\mathrm{CH}-\left(\mathrm{NH}-i-\mathrm{C}_{3} \mathrm{H}_{7}\right) \mathrm{NH}_{2}$ [28]; $-\mathrm{C}\left(\mathrm{NEt}_{2}\right)\left(i-\mathrm{C}_{3} \mathrm{H}_{7}\right)-\mathrm{CH}\left(\mathrm{NH}-i-\mathrm{C}_{3} \mathrm{H}_{7}\right) \mathrm{NH}_{2}$ [28]; $-\mathrm{CH}_{2}-\mathrm{C}\left(\mathrm{Me}_{2}\right)-\mathrm{CH}_{2} \mathrm{NEt}_{2}$ [28]; - $\left(\mathrm{CH}_{2}\right)_{2}-\mathrm{O}-\left(\mathrm{CH}_{2}\right)_{2} \mathrm{NH}_{2}$ [29]; $-\left(\mathrm{CH}_{2}\right)_{3}-\mathrm{NH}-n-\mathrm{C}_{4} \mathrm{H}_{9}$ [29]; $-\mathrm{CH}(\mathrm{Me})-$ $\left(\mathrm{CH}_{2}\right)_{3} \mathrm{NEt}_{2}[30] ;-\left(\mathrm{CH}_{2}\right)_{\mathrm{n}} \mathrm{NH}_{2}, \mathrm{n}=3-4[29,30] ;-\left(\mathrm{CH}_{2}\right)_{\mathrm{n}}-\mathrm{NH}-\left(\mathrm{CH}_{2}\right)_{\mathrm{n}} \mathrm{NH}_{2}$, $\mathrm{n}=3-4$ [31]; $-\left(\mathrm{CH}_{2}\right)_{3}-\mathrm{N}\left[\left(\mathrm{CH}_{2}\right)_{3} \mathrm{NH}_{2}\right]_{2}$ [32]; $-\left(\mathrm{CH}_{2}\right)_{3}-\mathrm{NH}\left(\mathrm{CH}_{2}\right)_{11} \mathrm{NEt}_{2}$ [32]; $-\left(\mathrm{CH}_{2}\right)_{3}-\mathrm{NH}\left(\mathrm{CH}_{2}\right)_{\mathrm{n}} \mathrm{CH}_{3}, \mathrm{n}=0-3$ and 6 [33]; $-\left(\mathrm{CH}_{2}\right)_{3}-\mathrm{NH}-\mathrm{CH}(\mathrm{Me})-$ $\mathrm{CH}_{2} \mathrm{Ph}$ [33]; - $\left(\mathrm{CH}_{2}\right)_{3}-\mathrm{NHCH}_{2} \mathrm{Ar}, \mathrm{Ar}=$ Phenyl or 2-Furyl [33]; $-\left(\mathrm{CH}_{2}\right)_{3}-$ $\mathrm{NH}\left(\mathrm{CH}_{2}\right)_{2} \mathrm{NH}_{2}$ [33]; - $\mathrm{CH}(\mathrm{Me})-\left(\mathrm{CH}_{2}\right)_{\mathrm{n}}-\mathrm{NEt}_{2}, \mathrm{n}=1-2$ [34]; $-\left(\mathrm{CH}_{2}\right)_{\mathrm{n}}-\mathrm{X}-$ $\left(\mathrm{CH}_{2}\right)_{\mathrm{n}}-\mathrm{NEt}_{2}, \mathrm{X}=\mathrm{S}$ or $\mathrm{SO}_{2}$ and $\mathrm{n}=2$ or $3[35] ;-\left(\mathrm{CH}_{2}\right)_{3}-\mathrm{CH}\left(\mathrm{NH}_{2}\right)-n-\mathrm{C}_{4} \mathrm{H}_{9}$ [36];-CH(Me)-( $\left.\mathrm{CH}_{2}\right)_{2}-\mathrm{CH}(\mathrm{Me})-\mathrm{NRR}_{1}, \mathrm{R}=\mathrm{R}_{1}=$ Hor alkyl [36]; $-\left(\mathrm{CH}_{2}\right)_{\mathrm{n}} \mathrm{R}$, $\mathrm{n}=3-6$ and $\mathrm{R}=\mathrm{N}^{4}$-benzyl piperazinyl[36]; $-\mathrm{CH}_{2}-\mathrm{CH}(\mathrm{OH})-\left(\mathrm{CH}_{2}\right)_{2}-\mathrm{NHEt}$ [36]; $-\mathrm{CH}\left(\mathrm{C}_{2} \mathrm{H}_{5}\right)-\left(\mathrm{CH}_{2}\right)_{3} \mathrm{NEt}_{2}$ [37]; $-\left(\mathrm{CH}_{2}\right)_{\mathrm{n}}-\mathrm{S}-\left(\mathrm{CH}_{2}\right)_{\mathrm{n}} \mathrm{R}, \mathrm{n}=2$ or 3 and $\mathrm{R}=$ diethylamino, piperidino, morpholino or thiomorpholino [37]; 
$-\left(\mathrm{CH}_{2}\right)_{3} \mathrm{R}, \mathrm{R}=-\mathrm{NHCONH}_{2}$ or $-\mathrm{NHCH}_{2} \mathrm{SO}_{3} \mathrm{Na}$ or $-\mathrm{NH}-\mathrm{C}_{6} \mathrm{H}_{12} \mathrm{O}_{6}$ [38]; $-\mathrm{CH}(\mathrm{Me})-\left(\mathrm{CH}_{2}\right)_{4}-\mathrm{NRR}_{1}, \mathrm{R}=\mathrm{R}_{1}=\mathrm{H}$ or diethyl or $i$ propyl or $n$-propyl [39];- $\left(\mathrm{CH}_{2}\right)_{5} \mathrm{NHR}, \quad \mathrm{R}=-\mathrm{CH}(\mathrm{Me})-\left(\mathrm{CH}_{2}\right)_{2} \mathrm{CH}_{3}$ or $-\mathrm{CH}\left(\mathrm{C}_{2} \mathrm{H}_{5}\right)_{2}$ or $-\mathrm{CH}(\mathrm{Me}) \mathrm{C}_{2} \mathrm{H}_{5}$ or $-\left(\mathrm{CH}_{2}\right)_{4} \mathrm{CH}_{3}$ or $-\mathrm{CH}_{2}-\mathrm{C}(\mathrm{Me})_{3} \quad$ [40]; $-\left(\mathrm{CH}_{2}\right)_{\mathrm{n}} \mathrm{NRR}_{1}$, $\mathrm{n}=2-5$ and $\mathrm{R}=\mathrm{R}_{1}=\mathrm{H}$ or $-\mathrm{C}(=\mathrm{NH})-\mathrm{NH}_{2}$ [41]; $-\mathrm{CH}(\mathrm{Me})-\left(\mathrm{CH}_{2}\right)_{3} \mathrm{NRR}_{1}$, $\mathrm{R}=\mathrm{R}_{1}=-\mathrm{C}(=\mathrm{NH})-\mathrm{NH}_{2}[41] ;-\left(\mathrm{CH}_{2}\right)_{\mathrm{n}} \mathrm{NHR}, \mathrm{n}=4$ or $5, \mathrm{R}=\mathrm{CH}\left(\mathrm{CH}_{3}\right)_{2}$ [42]; $-\mathrm{CO}\left(\mathrm{CH}_{2}\right)_{3} \mathrm{NEt}_{2}$ [43]; $-\left(\mathrm{CH}_{2}\right)_{\mathrm{n}} \mathrm{R}, \mathrm{R}=2$-piperidyl and $\mathrm{n}=2-7$ [44].<smiles>[R]CNc1cccc2cccnc12</smiles>

Description of the nuclear substituents in 8-aminoquinolines $\left(R_{1}=\right.$ side chains related to pamaquine, primaquine, plasmocid, etc.)

6-OR, $\mathrm{R}=\mathrm{C}_{2} \mathrm{H}_{5}, n-\mathrm{C}_{4} \mathrm{H}_{9}$ or $\left(\mathrm{CH}_{2}\right)_{3} \mathrm{NH}_{2}[29,30,47] ; 5-\mathrm{Me}-6-\mathrm{OMe}-6-$ $\mathrm{OMe}$ [48]; 6- $\mathrm{OC}_{6} \mathrm{H}_{5}$ [43]; 5-OAr-6-OMe [45]; 5- $\mathrm{C}_{6} \mathrm{H}_{5}-6-\mathrm{OMe}$ [46]; 4 $\mathrm{Me}-6-\mathrm{OMe}$ [49]; 4-R-6-OMe, $\mathrm{R}=\mathrm{C}_{6} \mathrm{H}_{5}$ or $\mathrm{CO}_{2} \mathrm{C}_{2} \mathrm{H}_{5}$ or $\mathrm{CH}_{2} \mathrm{OH}$ or $\mathrm{CHO}$ or $\mathrm{CH}(\mathrm{Me})_{2}$ [50]; 5-Cl-6-OMe [31].

These modifications were aimed at obtaining 8-aminoquinoline derivatives which would be less toxic than primaquine. The major thrust, therefore, was on the synthesis of primaquine analogs. The details are presented below.

\section{$2.21 \quad$ 2-Substituted primaquine analogs}

The suppressive activity of VII-XIX has been assessed against $P$. berghei infection in mice according to the method of Rane et al. [20]. Compounds VII-IX, XI and XIV were active but, except for IX, the rest of the compounds showed primaquine like toxicity [53,54]. Of the various 2-benzyloxy and thiobenzyloxy derivatives of primaquine (XV-XIX) screened, only compounds XV and XVI have been identified as blood schizontocides against $P$. berghei infection in mice at a dose level of $640 \mathrm{mg} / \mathrm{kg}$ [51, 54]. Compound XVII was found to be ac-<smiles>[R]c1ccc2cc(OC)cc(NC(C)CCCN)c2n1</smiles> 


\begin{tabular}{llll}
$\begin{array}{lll}\text { Compound } \\
\text { No. }\end{array}$ & $\mathrm{R}$ & $\begin{array}{l}\text { Compound } \\
\text { No. }\end{array}$ & $\mathrm{R}$ \\
\hline VII: & $\mathrm{OCH}_{3}$ & $\mathrm{XIV}:$ & $\mathrm{N}\left(\mathrm{CH}_{3}\right)_{2}$ \\
VIII: & $\mathrm{Cl}$ & $\mathrm{XV}:$ & $p-\mathrm{F}-\mathrm{OCH}_{2} \mathrm{Ph}$ \\
IX: & $\mathrm{C}_{2} \mathrm{H}_{5}$ & $\mathrm{XVI}:$ & $o, p-\mathrm{Cl}_{2}-\mathrm{OCH}_{2} \mathrm{Ph}$ \\
X: & $\mathrm{OCH}_{2} \mathrm{Ph}$ & XVII: & $p-\mathrm{Cl}-\mathrm{SCH}_{2} \mathrm{Ph}$ \\
XI: & $\mathrm{CH}=\mathrm{CH}_{2}$ & XVIII: & $p-\mathrm{CF}_{3}-\mathrm{OCH}_{2} \mathrm{Ph}$ \\
XII: & $\mathrm{NH}_{2}$ & XIX: & $\mathrm{SCH}_{2} \mathrm{Ph}$ \\
XIII: & $\mathrm{NHCOCH}_{3}$ & & \\
\hline
\end{tabular}

tive at dose levels of 320 and $640 \mathrm{mg} / \mathrm{kg}$. Screening for radical curative activity in rhesus monkeys against $P$. cynomolgi infection has indicated that substituents such as methoxy (VII), chloro (VIII) and ethyl (IX) at position 2 of the quinoline nucleus abolished the radical curative activity $[52,53]$ but compounds XV, XVI, XVIII and XIX have been found to exhibit radical curative activity at a dose of $1 \mathrm{mg} / \mathrm{kg}$ (p.o.). The test has also shown that XV and XVIII are equipotent to primaquine but the compounds XVI and XIX are less active. However, dose for dose, compounds XV, XVI, XVIII and XIX have been found to be superior to $X$ which is curative at a dose of $1.5 \mathrm{mg} / \mathrm{kg}$. These results indicate that a substituted benzyloxy residue at position 2 of the quinoline nucleus does help in retaining the radical curative activity. It may be noted that compounds having substituents, such as fluorine, trifluoromethyl and chlorine on the benzyloxy residue are better tolerated by experimental animals. Dose for dose, none of the compounds is more active than primaquine.

\section{$2.22 \quad 3$-Substituted primaquine analogs}

Data regarding the radical curative activity of primaquine analogs having various substituents at position 3 are not available. It is likely that the earlier report about the blood schizontocidal activity of 3-substituted 8-aminoquinoline derivatives [55] might have discouraged the synthesis of 3-substituted primaquine derivatives. It would be pertinent to point out that after 1971 definite stress has been given to generating data relating to radical curative activity and it would be incorrect to presume that compounds having blood schizontocidal activity would also be effective as radical curative agents. 
Unlike the spectrum of substituents at position 2 of primaquine, in the 4-position alkyl residues consisting of straight or branched chains of 1-7 carbon atoms [56] have been studied as preferred molecular modification. Other modifications carried out include the introduction of a $\beta$-alkylvinyl moiety and alkylaryl thioethers [57] at position 4.<smiles>[R]c1ccnc2c([R])cc(OC)cc12</smiles>

\begin{tabular}{|c|c|c|}
\hline \multicolumn{2}{|c|}{$\begin{array}{l}\text { Compound } \\
\text { No. }\end{array}$} & \multirow{2}{*}{$\begin{array}{l}\mathrm{R}_{2} \\
\mathrm{CH}_{2}=\mathrm{CH}\end{array}$} \\
\hline XX: & $-\underset{I}{\mathrm{NH}}-\underset{\mathrm{Me}}{\mathrm{CH}}-\left(\mathrm{CH}_{2}\right)_{3} \cdot \mathrm{NH}_{2} \cdot$ fumarate & \\
\hline XXI: & $-\mathrm{NH}-\underset{\mathrm{I}}{\mathrm{C}} \mathrm{H}-\left(\mathrm{CH}_{2}\right)_{3} \cdot 2 \mathrm{HBr}$ & $\mathrm{CH}_{3} \mathrm{CH}_{2}$ \\
\hline XXII: & $-\mathrm{NH}-\underset{\mathrm{M}}{\mathrm{C}} \mathrm{H}-\left(\mathrm{CH}_{2}\right)_{3} \cdot \mathrm{NH}_{2} \cdot$ fumarate & $p-\mathrm{F}-\mathrm{C}_{6} \mathrm{H}_{4} \mathrm{~S}\left(\mathrm{CH}_{2}\right)_{2}$ \\
\hline XXIII: & $-\mathrm{NH}-\underset{\mathrm{M}}{\mathrm{C}} \mathrm{H}-\left(\mathrm{CH}_{2}\right)_{3} \cdot \mathrm{NH}_{2} \cdot \mathrm{H}_{3} \mathrm{PO}_{4}$ & $p-\mathrm{OCH}_{3}-\mathrm{C}_{6} \mathrm{H}_{4}-\mathrm{S}\left(\mathrm{CH}_{2}\right)_{2}$ \\
\hline
\end{tabular}

Compounds XX and XXI exhibit blood schizontocidal activity [20, 56]. The former causes $3 / 5$ cures at doses of 160 and $320 \mathrm{mg} / \mathrm{kg}$ and $2 / 5$ cures at $640 \mathrm{mg} / \mathrm{kg}$ but the last two doses have been found to be toxic. The latter compound, although active even at $160 \mathrm{mg} / \mathrm{kg}$, shows $2 / 5$ and $5 / 5$ cures at 320 and $640 \mathrm{mg} / \mathrm{kg}$, respectively. In this model primaquine exhibits activity at $80 \mathrm{mg} / \mathrm{kg}$. These results indicate that compounds $\mathrm{XX}$ and XXI are slightly less active than primaquine but are possibly better tolerated by experimental animals. Screening of compounds XX-XXII for radical curative activity against $P$. cynomologi infection in rhesus monkeys has revealed that at a dose of $1 \mathrm{mg} / \mathrm{kg}$, compound XXI is as active as primaquine (I) [56, 59], and at a dose of $0.5 \mathrm{mg} / \mathrm{kg}, \mathrm{XX}$ and XXII are less active. The causal prophylactic activity of compound XXIII against sporozoite induced $P$. berghei yoelii infection in rodents is evident from $2 / 5$ cures at a dose of $160 \mathrm{mg} / \mathrm{kg}$ 
(p. o.) but the compound is inactive upto a dose of $40 \mathrm{mg} / \mathrm{kg}$ (p.o.) [ 24 , 57]. It is also inactive at doses of 160,40 and $10 \mathrm{mg} / \mathrm{kg}$ (s. c.). The introduction of alkyl or substituted vinyl groups at position 4 of the quinoline nucleus (XXIV-XXVII) results in decrease of toxicity but the compounds retain their antimalarial activity [56].<smiles>[R]C=Cc1ccnc2c(NC(C)CCCN)cc(OC)cc12</smiles>
No.

XXIV:

XXV:

XXVI:

XXVII:
$\mathbf{R}$

$\mathrm{CH}_{3}$

$\mathrm{C}_{2} \mathrm{H}_{5}$

$\mathrm{C}_{6} \mathrm{H}_{11}$

$\mathrm{CH}_{3}$ (cis)<smiles>[R]c1ccnc2c(NC(C)CCCN)cc(OC)cc12</smiles>

$\mathbf{R}$
Compound No.

XXVIII:

XXIX:

XXX:

XXXI:

XXXII:

$\mathrm{C}_{3} \mathrm{H}_{7}$ $\left(\mathrm{CH}_{2}\right)_{3} \mathrm{CH}_{3}$ $\left(\mathrm{CH}_{2}\right)_{3} \mathrm{C}_{6} \mathrm{H}_{11}$

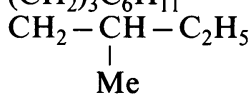

Evaluation of the prophylactic activity of XXIV-XXXII against sporozoite induced $P$. berghei yoelii in rodents has revealed that all the compounds except XXVI and XXX are active at a dose of $160 \mathrm{mg} / \mathrm{kg}$ $[56,61]$. However, these compounds do not show radical curative activity against $P$. cynomolgi infection in rhesus monkeys $[56,59]$ but compound XXV exhibits blood schizontocidal activity against $P$. berghei in mice $[20,56]$ at $80-640 \mathrm{mg} / \mathrm{kg}$. These results suggest that increasing the length of the saturated or unsaturated alkyl chain at position 4 in primaquine results in loss of activity [60].

\section{$2.24 \quad 5$-Substituted primaquine analogs}

Anilino, thiophenyl and phenoxy residues with substituents on the phenyl ring XXXIII-XLV as pharmacophores at the position 5 of the quinoline ring have been studied $[64,65]$. A number of thiophenyl primaquines XXXIII-XL exhibit radical curative activity and amongst these, XXXV and XXXIX give cures at $1 \mathrm{mg} / \mathrm{kg}$ but their order of ac- 
tivity is less than that of primaquine which produces $10 / 12$ cures at 0.5 $\mathrm{mg} / \mathrm{kg}$. Early relapse occurs with the anilino derivative XLI at 1 and $10 \mathrm{mg} / \mathrm{kg}$ [64]. In the blood schizontocidal screen [63] all the compounds are inactive at $640 \mathrm{mg} / \mathrm{kg}$ except XXXVIII which exhibits weak antimalarial activity at doses of 320 and $640 \mathrm{mg} / \mathrm{kg}$ and is less toxic. The substituents such as 5-thiophenyl, anilino or phenoxy have been found to diminish the toxicity of primaquine but only the phenoxy moiety does not affect the antimalarial activity [64].

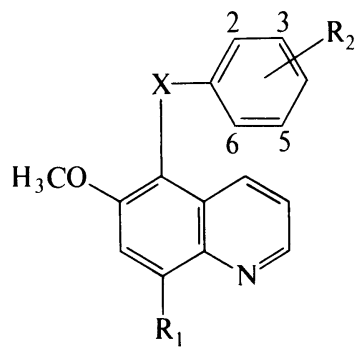

\begin{tabular}{llll}
$\begin{array}{l}\text { Compound } \\
\text { No. }\end{array}$ & $\mathrm{X}$ & \multicolumn{1}{c}{$\mathrm{R}_{1}$} & $\mathrm{R}_{2}$ \\
\hline XXXIII: & $\mathrm{S}$ & $\mathrm{CH}_{3} \mathrm{CH}(\mathrm{NH})\left(\mathrm{CH}_{2}\right)_{3} \mathrm{NH}_{2}$ & $2-\mathrm{Cl}$ \\
XXXIV: & $\mathrm{S}$ & $\mathrm{CH}_{3} \mathrm{CH}(\mathrm{NH})\left(\mathrm{CH}_{2}\right)_{3} \mathrm{NH}_{2} \cdot \mathrm{H}_{2} \mathrm{O}$ & $3-\mathrm{Cl}$ \\
XXXV: & $\mathrm{S}$ & $\mathrm{CH}_{3} \mathrm{CH}(\mathrm{NH})\left(\mathrm{CH}_{2}\right)_{3} \mathrm{NH}_{2}$ & $4-\mathrm{Cl}$ \\
XXXVI: & $\mathrm{S}$ & $\mathrm{CH}_{3} \mathrm{CH}(\mathrm{NH})\left(\mathrm{CH}_{2}\right)_{3} \mathrm{NH}_{2}$ & $3,4-\mathrm{Cl}_{2}$ \\
XXXVII: & $\mathrm{S}$ & $\mathrm{CH}_{3} \mathrm{CH}(\mathrm{NH})\left(\mathrm{CH}_{2}\right)_{3} \mathrm{NH}_{2}$ & $2,5-\mathrm{Cl}_{2}$ \\
XXXVIII: & $\mathrm{S}$ & $\mathrm{CH}_{3} \mathrm{CH}(\mathrm{NH})\left(\mathrm{CH}_{2}\right)_{3} \mathrm{NH}_{2} \cdot$ citrate & $4-\mathrm{OCH}_{3}$ \\
XXXIX: & $\mathrm{S}$ & $\mathrm{CH}_{3} \mathrm{CH}(\mathrm{NH})\left(\mathrm{CH}_{2}\right)_{3} \mathrm{NH}_{2} \cdot \frac{1}{2} \mathrm{H}_{2} \mathrm{O}$ & $3-\mathrm{CF}_{3}$ \\
XL: & $\mathrm{S}$ & $\mathrm{CH}_{3} \mathrm{CH}(\mathrm{NH})\left(\mathrm{CH}_{2}\right)_{3} \mathrm{NH}_{2} \cdot \mathrm{H}_{2} \mathrm{O}$ & $3,4-$ benzo \\
XLI: & $\mathrm{NH}$ & $\mathrm{CH}_{3} \mathrm{CH}(\mathrm{NH})\left(\mathrm{CH}_{2}\right)_{3} \mathrm{NH}_{2}$ & $3-\mathrm{CF}_{3}$ \\
\hline
\end{tabular}

In the murine blood schizontocidal screen, XLII-XLIV have been found to exhibit [65] less toxicity even at $640 \mathrm{mg} / \mathrm{kg}$ compared to primaquine (I) which is toxic at $160 \mathrm{mg} / \mathrm{kg}$. Compound XLIV possesses antimalarial activity equivalent to that of primaquine at lower doses and causes total cure at 320 and $640 \mathrm{mg} / \mathrm{kg}$. Compounds XLIII and XLIV are more effective than XLII. In the monkey screen radical cures have been obtained with XLIII and XLIV at doses of $0.5,0.75$ or $1 \mathrm{mg} / \mathrm{kg}$ and of these two, compound XLIV is considered as the better candidate. However, replacement of the lipophilic halo groups by the hydrophilic acetamido moiety abolishes the antimalarial activity. 
<smiles>[R2]NCCCC(C)Nc1cc(OC)c([R])c2cccnc12</smiles>

\begin{tabular}{lll} 
Compound & & \multicolumn{1}{c}{$\mathrm{R}_{1}$} \\
No. & & $\mathrm{R}_{2}$ \\
\hline XLII: & $\mathrm{OPh}$ & $\mathrm{H}_{3} \mathrm{PO}_{4} \cdot 5 \mathrm{H}_{2} \mathrm{O}$ \\
XLIII: & $p-\mathrm{Cl}-\mathrm{OPh}$ & $\mathrm{H}_{2} \mathrm{O}$ \\
XLIV: & $p-\mathrm{F}-\mathrm{OPh}$ & Citrate $\cdot \frac{1}{2} \mathrm{H}_{2} \mathrm{O}$ \\
XLV: & $p-\mathrm{CH}_{3} \mathrm{CONH}-\mathrm{OPh}$ & $\mathrm{HCl}$ \\
\hline
\end{tabular}

Of the various phenoxy substituted primaquines, compounds XLVI, LII and LV exhibit radical curative activity equal to that of primaquine and are tolerated better by experimental animals [66]. It has been observed that a 3-trifluoromethyl or 4-fluorophenoxy substituent is essential for better curative activity.

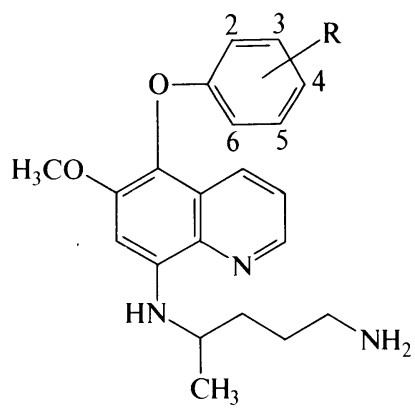

\begin{tabular}{llll} 
Compound & \multicolumn{1}{c}{$\mathrm{R}$} & \multicolumn{1}{c}{ Compound } & \multicolumn{1}{c}{$\mathrm{R}$} \\
No. & & No. & \\
\hline XLVI: & $3-\mathrm{CF}_{3}$ & LI: & $3,5-\left(\mathrm{CF}_{3}\right)_{2}$ \\
XLVII: & $4-\mathrm{OCF}_{3}$ & LII: & $4-\mathrm{F}, 3-\mathrm{CF}_{3}$ \\
XLVIII: & $4-\mathrm{OCH}_{3}$ & LIII: & $\mathrm{H}$ \\
XLIX: & $2,4-\mathrm{Cl}_{2}$ & LIV: & $4-\mathrm{Cl}$ \\
L: & $3,4-\mathrm{Cl}_{2}$ & LV: & $4-\mathrm{F}$ \\
\hline
\end{tabular}

With the exception of XLVII, these compounds are not lethal even at $640 \mathrm{mg} / \mathrm{kg}$ and even XLVII is less toxic than primaquine. The most ac- 
tive blood schizontocides identified in the screen are XLVI and LV and compound LII is less active than XLVI or LV.

\subsection{4,5-Disubstituted primaquines analogs}

The encouraging radical curative activity of 4-methylprimaquine and 5-phenoxyprimaquine possibly led to the synthesis and antimalarial screening of 4-alkyl-5-alkoxyprimaquines [67, 68]. It has been observed that compounds LVI, LIX and LX have better curative activity than primaquine and slight modification in the side chain attached to the amino group at position 8 of the quinoline nucleus does not affect the activity [67-69].<smiles>[R]c1ccc(Oc2c(OC)cc(NC(C)CCCN)c3ncccc23)cc1</smiles>

\begin{tabular}{lll} 
Compound & $\mathrm{R}$ & $\mathrm{R}$ \\
No. & & \\
\hline LVI: & $4-\mathrm{CH}_{3}$ & $3-\mathrm{CF}_{3}$ \\
LVII: & $4-\mathrm{CH}_{3}$ & $2,4-\mathrm{Cl}_{2}$ \\
LVIII: & $4-\mathrm{CH}_{3}$ & $3,4-\mathrm{Cl}_{2}$ \\
LIX: & $4-\mathrm{CH}_{3}$ & $4-\mathrm{OCH}_{3}$ \\
LX: & $4-\mathrm{CH}_{3}$ & $4-\mathrm{F}$ \\
LXI: & $4-\mathrm{CH}_{3}$ & $\mathrm{H}$ \\
LXII: & $4-\mathrm{CH}_{3}$ & $3,5-\left(\mathrm{CF}_{3}\right)_{2}$ \\
LXIII: & $3-\mathrm{CH}_{3}$ & $4-\mathrm{F}, 3-\mathrm{CF}_{3}$ \\
LXIV: & $4-\mathrm{CH}_{3}$ & $4-\mathrm{F}, 3-\mathrm{CF}_{3}$ \\
\hline
\end{tabular}

The introduction of an additional methyl group at position 2 of the quinoline ring invariably reduces the efficacy of the compound. Compounds LVI, LIX and LX show $100 \%$ curative activity at a dose of $0.316 \mathrm{mg}$ (salt) $/ \mathrm{kg}$ per day for 7 days compared to $1.3 \mathrm{mg} / \mathrm{kg}$ per day $\times$ 7 for primaquine. 
The compounds LXI and LXIII are lethal while LXII and LXIV have been reported to exhibit better blood schizontocidal activity than their non methyl analogs [67, 68]. A methyl group at position 4 is more effective than at position 3, although 4-methylprimaquine without a 5phenoxy residue is quite inactive.

Compound LVI-LX exhibit a very high level of activity in the Rane model for suppressive activity against $P$. berghei in mice [20]. One of these is curative at $5 \mathrm{mg} / \mathrm{kg}$ while the rest are active at $5 \mathrm{mg} / \mathrm{kg}$. In monkeys LVI gives $100 \%$ cure at $1 \mathrm{mg} / \mathrm{kg} \times 7$ and is only suppressive at the lower dose of $0.0316 \mathrm{mg} / \mathrm{kg}$ per day $(\times 7)$. Primaquine only suppresses but does not cure parasitaemia at doses of $1 \mathrm{mg}$ to $31.6 \mathrm{mg} / \mathrm{kg}$ per day [67, 68]. Compounds LVI-LX represent a definite breakthrough in the chemotherapy of malaria because they also possess blood schizontocidal activity comparable to that of amino alcohols. Besides the 5-phenoxy derivatives of 4-methylprimaquine, compounds possessing 5-methoxy derivatives also show an interesting profile of antimalarial activity [67].<smiles>[R]c1cc([R])c2c(OC)c(OC)cc([R15])c2n1</smiles>

\begin{tabular}{|c|c|c|c|}
\hline $\begin{array}{l}\text { Compound } \\
\text { No. }\end{array}$ & $\mathrm{R}_{1}$ & $\mathrm{R}_{2}$ & $\mathrm{R}_{3}$ \\
\hline LXV: & $\mathrm{H}$ & $\mathrm{CH}_{3}$ & $\begin{array}{c}-\underset{l}{\mathrm{CH}}-\left(\mathrm{CH}_{2}\right)_{3} \mathrm{NH}_{2} \\
\mathrm{Me}\end{array}$ \\
\hline LXVI: & $\mathrm{H}$ & $\mathrm{CH}_{3}$ & $-\left(\mathrm{CH}_{2}\right)_{3}-\underset{\mid}{\mathrm{CH}}-\mathrm{NH}_{2}$ \\
\hline LXVII: & $\mathrm{H}$ & $\mathrm{CH}_{3}$ & $-\underset{1}{\mathrm{CH}}-\left(\mathrm{CH}_{2}\right)_{3}-\mathrm{NH}_{2}$ \\
\hline LXVIII: & $\mathbf{H}$ & $\mathrm{CH}_{3}$ & $\begin{array}{c}\mathrm{CH}_{2} \mathrm{CH}_{3} \\
-\left(\mathrm{CH}_{2}\right)_{4}-\underset{l}{\mathrm{CH}}-\mathrm{NH}_{2} \\
\mathrm{Me}\end{array}$ \\
\hline LXIX: & $\mathrm{CH}_{3}$ & $\mathrm{CH}_{3}$ & $-\underset{\mathrm{M}}{\mathrm{C}} \mathrm{H}-\left(\mathrm{CH}_{2}\right)_{3}-\mathrm{NH}_{2}$ \\
\hline LXX: & $\mathbf{H}$ & $\mathrm{CH}_{3}$ & $\begin{array}{c}-\underset{1}{\mathrm{CH}}-\left(\mathrm{CH}_{2}\right)_{4}-\mathrm{NH}_{2} \\
\mathrm{Me}\end{array}$ \\
\hline
\end{tabular}


The suppressive antimalarial activity of LXV, LXVI, LXVIII, LXIX, LXXI and LXXII against $P$. berghei infection has been observed at doses lower than those of primaquine and 4-methylprimaquine [62, 67]. Compounds LXV, LXVI and LXX are active at 40, 20 and 1.25 $\mathrm{mg} / \mathrm{kg}$, respectively. Compound LXX is curative at $20 \mathrm{mg} / \mathrm{kg}$ while compounds LXXI and LXXII are active at $5 \mathrm{mg} / \mathrm{kg}$. However, none of the compounds are less toxic than primaquine but they possess high level of suppressive and radical curative activities. In the radical curative antimalarial screen, out of eleven compounds tested, only LXV and LXVII were found to effect cures at a dose of $0.125 \mathrm{mg} / \mathrm{kg}$ per day. A comparative study of the curative activity of various compounds at $0.25 \mathrm{mg} / \mathrm{kg}$ per day has indicated that primaquine is not curative at this dose, while 4-methylprimaquine gives $57 \%$ cure and compounds LXV and LXVI

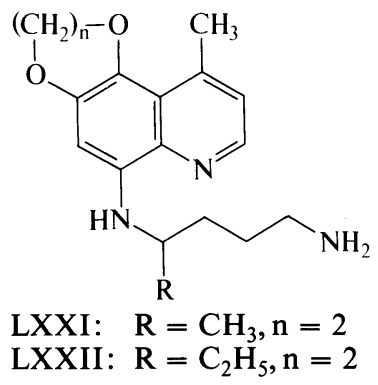

exhibit 75 and $83 \%$ cures, respectively. However, $100 \%$ curative activity has been found in compounds LXVII and LXVIII [67].
2.26 The contribution of the quinoline ring towards curative activity

Three types of molecular modifications have been carried out to ascertain the role of the quinoline ring system as a whole. The first one relates to a change in the pyridine part of the quinoline ring. The representative compounds of this modification namely the dihydro derivatives LXXIII and LXXIV exhibit curative activity against $P$. cynomolgi infection in rhesus monkeys at $10 \mathrm{mg} / \mathrm{kg}$ [70], but are inactive at $1 \mathrm{mg} / \mathrm{kg}$.

On the basis of the possible mode of action of primaquine, a second molecular modification has been made in which the quinoline ring has been replaced by a naphthalene residue. Of the various compounds screened, LXXV 
<smiles>[X]c1c(OC)cc(NC(C)CCCN)c2c1C=CCN2C</smiles>

LXXIII: $\quad \mathrm{X}=\mathrm{H}$

LXXIV: $\quad \mathrm{X}=\mathrm{OCH}_{3}$<smiles>[X]c1ccc2c(OC)c(OC)cc(NCCCC(C)N)c2c1</smiles>

LXXV: $\quad \mathrm{X}=\mathrm{Br}$

LXXVI: $\mathrm{X}=\mathrm{H}$<smiles>[R]c1c2ccccc2nc2c(NC(C)CCCN)cc(OC)cc12</smiles>

LXXVII: $\quad \mathrm{R}=\mathrm{H}$

LXXVIII: $\mathrm{R}=\mathrm{CH}_{3}$

exhibited curative activity at $10 \mathrm{mg} / \mathrm{kg}$ [71] and was less toxic than (LXXVI). This suggests that a bromine atom at C-6 decreases the toxicity and maintains the radical curative activity.

The third modification is the synthesis of 4-amino-2-methoxyacridine derivatives which represent the 2,3-benzo analog of primaquine. The two analogs LXXVII-LXXVIII evaluated for tissue schizontocidal activity are less active than primaquine [72].

Biochemistry, pharmacokinetics and metabolism of 8-aminoquinoline antimalarials

\section{1}

Biochemistry

Two main reasons can be ascribed for the widespread interest in studying the effect of 8-aminoquinoline antimalarials on the biochemical apparatus of host and parasite. These are the necessity of a proper understanding of the biochemical processes which may lead to side effects and the elucidation of the mode of antiparasitic action of these compounds. A number of biochemical models have been developed to study various enzyme systems but the extrapolation of the results obtained in these studies to clinical situations has to be done with cau- 
tion. The effect of 8-aminoquinoline antimalarials on various enzyme systems is described below.

\subsection{Effect on aminoacylation of $t$-RNA and polypeptide} synthesis

Primaquine has been reported to inhibit the aminoacylation of $t$-RNA and cause a dose-dependent inhibition of phenylalanine incorporation into the aminoacyl-t-RNA complex of the subcellular liver system of rat [73-76]. Primaquine also inhibits peptidyl transferase which would suggest that the drug induced inhibition of protein synthesis is possibly mediated by the inhibition of peptide bond formation, which in turn may contribute to the antimalarial activity and toxicity of primaquine. This drug inhibits the polypeptide formation directed by poly(U) or poly $(A, G, U)$ in rat liver cell free system [76]. Primaquine has been found to cause a considerable inhibition of the uptake and incorporation of ${ }^{14} \mathrm{C}$ labelled amino acids into synchronized cells of Tetrahymena pyriformis [77]. It also retards the incorporation of amino acids into proteins of virus infected chicken embryo cells [78] and, when added to the culture medium of Bacillus megatorium, it completely inhibits their protein biosynthesis [79].

\subsection{Effect on phospholipid metabolism and lipid biosynthesis}

Pentaquine greatly alters the phospholipid metabolism and osmotic stability of human red cells. It also decreases the content of reduced glutathione in erythrocytes [80]. Primaquine inhibits the incorporation of acetate into lipids by a cell free system from $T$. pyriformis. This suggests that the inhibition of lipid synthesis can lead to alteration of the membranes and thus to the inhibition of cell division and growth [81].

3.13 Effect on nucleic acid synthesis, phosphorylation of adenosine and incorporation of AMP

Primaquine exhibits little inhibitory effect on the synthesis of RNA and DNA by intact nuclei or solubilized polymerases of $T$. pyriformis [82]. It has no effect on the phosphorylation of adenosine by erythrocyte free malarial parasite [83] but inhibits the incorporation of AMP$8-{ }^{3} \mathrm{H}$ into nucleic acids [84]. 


\subsection{Interaction with nucleic acids}

Pentaquine and primaquine bind appreciably with DNA but do not cause a significant change in the transition temperature or the viscosity of the DNA. On the other hand, their interaction with RNA results in increasing the sensitivity of the latter to enzymatic hydrolysis by several nucleases. Primaquine does not have any noteworthy effect on aminoacylation of $t$-RNA in mouse liver system [85]. In $T$. pyriformis, primaquine inhibits the synthesis of RNA and DNA as shown by the inhibited uptake of thymidine, uridine and amino acid [86]. However, leucine incorporation into the hepatic proteins in rats and mice remains unaffected [87]. 8-Aminoquinolines have been reported to possess inhibitory effect on certain bacterial DNA polymerases [88].

\subsection{Effect on energetics of mitochondria}

Primaquine inhibits oxidative phosphorylation in isolated $T$. pyriformis mitochondria [89]. A study of the effect of primaquine on auto-oxidation of isolated chains from human haemoglobin has shown that the drug enhances the precipitation of isolated oxidized chains and that the process is independent of oxygen radical [90]. Studies on primaquine induced alteration of glucose metabolism in uninfected red cells have revealed an increased flux of glucose through the hexose monophosphate shunt in these cells [91].

\subsection{Effect on other enzyme systems}

It has been suggested that primaquine possibly inhibits active sodium transport directly as evident from the inhibition of the short circuit current and $\mathrm{Na}^{+} \mathrm{K}^{+}-$ATPase in toad bladder [92]. Primaquine also inhibits alcohol dehydrogenase of human liver, reversibly and non-competitively with respect to NAD. The terminal primary amino group of the primaquine side chain possibly contributes towards the tight binding of this drug with the enzyme [93].

\subsection{Pharmacokinetics}

The study of the absorption, plasma concentration, tissue distribution and excretion of 8 -aminoquinoline antimalarials prior to 1970 , has 
shown that pamaquine and other 8-aminoquinolines are absorbed rapidly from the gastrointestinal tract of monkeys and that the absorption is $85-95 \%$ within 2 hours of drug administration [94]. Since the plasma concentration of pamaquine in humans is approximately the same, 3 hours after administration of the drug, whether oral or intramuscular, it has been concluded that the absorption is rapid and complete $[95,96]$. The plasma level of pamaquine has been the subject of extensive investigations. Administration of pamaquine in three doses of $10 \mathrm{mg}$ each leads to a peak plasma concentration 2-4 hours after the individual dose, but after 8 hours the concentration is found to be negligible [96]. The individual variation of the plasma level is very high. For example, in a group of ten subjects receiving $60 \mathrm{mg}$ of pamaquine daily for 6 days, the plasma level of the drug ranges between $39 \gamma / 1$ and $2,000 \gamma / 1$ [96-98]. Study of the tissue distribution of pamaquine in dogs and monkeys indicates that the concentration of the drug in liver, lung and spleen is higher than in the plasma; the lowest concentration is, however, in brain [94]. Earlier studies on excretion of pamaquine had furnished very little information. For example, after a serial oral dose of pamaquine given daily to patients, the urinary excretion was only $1 \%$ of the total dose [99], although the disappearance of $95 \%$ of the drug 15 minutes after administration has been noted in humans [96]. Possibly the lack of adequate information from earlier studies led to renewed interest in the kinetics and metabolism of 8-aminoquinolines in man. Recent studies on the pharmacokinetics of a single dose of primaquine in humans have revealed that the drug is almost completely eliminated from the blood within 24 hours by excretion, metabolism and tissue localization [100]. However, $\mathrm{G}_{6}$ PD deficiency, does not affect the plasma primaquine concentration. It has been observed that in humans only a maximum of $2 \%$ of the administered dose of $45 \mathrm{mg}$ of primaquine can be detected in the blood plasma [100]. Excretion of unconjugated primaquine in urine remains extremely low over a period of 24 hours. Tracer studies with ${ }^{14} \mathrm{C}$ labelled primaquine in rat indicated a considerable amount of excretion in faeces [100]. Studies with ${ }^{14} \mathrm{C}$ ring labelled primaquine have indicated an extensive enterohepatic circulation of the drug in rats. No accumulation of the drug in the blood plasma has been observed after multiple dose of primaquine over a period of 5 days. This study, therefore, indicates that multiple dosing has very little effect on plasma primaquine kinetics and that no correlation can be drawn between the amount of primaquine excreted 
and the level of methaemoglobin [100]. In vitro studies on the fate of primaquine in mice liver homogenate have shown that rapid elimination of the side chain attached to position 8 of the quinoline nucleus takes place [101].

Tissue distribution of primaquine has been studied in rats after intraperitoneal administration. The half-life of unmetabolized primaquine is 4 hours in lung, 1.7-1.9 hours in blood, spleen, kidney and heart and 1.2 hours in liver [102]. Its concentration is highest in lung, followed by liver, kidney, spleen, heart, brain and blood.

\subsection{Metabolism}

Studies on the metabolism of 8-aminoquinolines such as pamaquine, pentaquine, isopentaquine and primaquine, prior to 1975 had shown that dealkylation of the 6-methoxy group and hydroxylation at position 5 result in the formation of 5,6-dihydroxy derivatives [103-104]. Baty in 1975, with the help of gas chromatography and mass spectrometry, reported the formation of 8-amino-6-methoxyquinoline as a metabolite in male subjects [105]. Field desorption mass spectrometric studies of the urinary metabolites of primaquine and other quinolines in mice have indicated the presence of 8-amino-6-methoxyquinoline, 8-amino-6-hydroxyquinoline and 8-amino-5,6-dihydroxyquinoline [101]. Recent metabolic studies in dogs have shown that after administration of tritiated primaquine, $13.4 \%$ of the radioactivity is excreted in the urine upto 5 hours and $16 \%$ upto 8 hours [106]. In dog the halflife of this drug in biophase is about 21 hours. The presence of four or five metabolic products of primaquine in dog urine has been observed and of these only two have been identified by comparison with model metabolites, as 6-hydroxy-8-(4-amino-1-methylbutylamino)quinoline and 5-hydroxy-6-methoxy-8-(4-amino-1-methylbutylamino)quinoline, arising by demethylation and hydroxylation, respectively of pri-

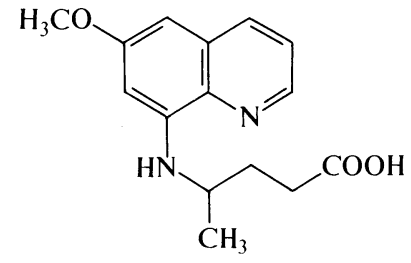

LXXX<smiles>COc1cc(NC(C)CCCNC(C)=O)c2ncccc2c1</smiles>

LXXIX 
maquine [106]. Two compounds namely, 8-(4-acetamido-1-methylbutylamino)-6-methoxyquinoline (LXXIX) and 8-(3-carboxyl-1-methylpropylamino)-6-methoxyquinoline (LXXX) have been identified as microbial metabolites of this drug and one of them (LXXX) has also been isolated as mammalian metabolite [107].

Mechanism of action, side effects, toxicity and miscellaneous studies

\subsection{Mechanism of action}

A possible mechanism of action of 8-aminoquinolines was reported by Smith in the mid-50's. Studies carried out with radiolabelled pentaquine in rhesus monkeys have indicated that the drug is metabolized to redox active 5,6-quinone derivatives [108, 103]. In the early 60 's the similarity of naphthaquinone antimalarial drugs, such as menoctone with these metabolites of 8-aminoquinolines was recognized. Menoctone inhibits the ubiquinone linked mitochondrial enzyme system and serves as a link for understanding the mechanism of action of 8-aminoquinolines [18, 148]. A recent publication of Gutteridge and Coombes suggests that the mode of action of naphthaquinones and primaquine can serve as a link between ubiquinone and pyrimidine synthesis [109]. The plausible mechanism involves the enzyme dihydroorotate dehydrogenase, an important enzyme for pyrimidine synthesis [109]. The enzyme is linked to the oxidation reduction of ubiquinone and the presence of a redox agent such as a quinoline quinone system can be expected to interfere with the ubiquinone oxidation reduction process and may thus disrupt the synthesis of pyrimidine in plasmodia. Dihydroorotate dehydrogenase has been demonstrated in $P$. berghei and $P$. knowlesi $[110,111]$. An alternative mechanism, suggested by Lantz and Vandyke [112], is the inhibition of uptake of tritiated ATP by RNA, which may be due either to blockade of the DNA template or to inhibition of RNA polymerase, but the doses required to elicit these effects are considered to be too high. A few studies on the effect of 8-aminoquinolines on nucleic acids suggest that the former interfere with several RNA functions as well as nucleic acid synthesis $[113,114]$. However, these data are insufficient for elucidating the mechanism of action in man. 


\subsection{Side effects of 8 -aminoquinolines}

A large number of side effects, recorded between 1940 and 1960, are of interest for understanding various enzyme interactions. Gastrointestinal disturbances associated with nausea, vomiting, anorexia, dizziness, epigastric distress and abdominal pains are the most frequently observed side effects of 8 -aminoquinolines. The abdominal pain is dose-dependent and administration of the drug at meal time has been found to increase abdominal distress [115]. The effect of these compounds on leucocytes has also been studied. In humans, neutropenia and agranulocytosis have been observed with large daily doses of pamaquine, pentaquine or primaquine but 10 to $30 \mathrm{mg}$ of primaquine daily for 14 days does not cause leucocytosis or leucopenia [94, 116]. 8-Aminoquinolines convert haemoglobin into methaemoglobin. Methaemoglobinaemia occurs when the oxygen carrying ferrous haemoglobin is oxidized to non-oxygen carrying ferric form and accumulates in the circulating erythrocytes. Clinically methaemoglobinaemia manifests itself as cyanosis [117]. It has been observed that in $\mathrm{G}_{6} \mathrm{PD}$ deficient individuals receiving primaquine, methaemoglobinaemia is less evident compared to normal individuals on the same dose. The reason ascribed by Brewer is the destruction of older cells in sensitive individuals while in normal subject this does not occur [118]. Haemolytic anaemia is the most serious toxic hazard of primaquine and other 8aminoquinolines observed for $\mathrm{G}_{6} \mathrm{PD}$ deficient erythrocytes [119]. The genetic link of this deficiency has been studied and of the many molecular variants of $\mathrm{G}_{6} \mathrm{PD}$, the principle ones are the $\mathrm{GdA}^{-}$variant that occurs in the haemoglobin of individuals of African descent and the $\mathrm{GdB}^{-}$occurring in inhabitants of Mediterranian region [120]. $\mathrm{G}_{6} \mathrm{PD}$ deficient erythrocytes are incapable of rapid generation of reduced NADPH [119]. The haemolytic effects of primaquine are changes in ultrastructure of membrane and vacuolization [121-123]. Besides these, the effect of 8-aminoquinolines on the cardiovascular pharmacology has also been studied. Frequent high doses of pentaquine monophosphate cause postural hypotension [124] which can possibly be explained in terms of impairment of the central sympathetic system.The impairment of sympathetic cardiovascular reflexes with higher doses of pamaquine, pentaquine and isopentaquine was observed in dogs and monkeys around 1950 [125]. Pamaquine and primaquine exhibit quinidine like effects on the myocardium [126, 127]. Primaquine 
shows better antiarrhythmic effect in experiments in which arterial fibrillation is induced by intravenous injection of acetylcholine into neostigmin pretreated animals. Pamaquine and primaquine inhibit the initiation, atrioventricular conduction and intraventricular transmission of impulses [127].

Continued interest in the side effects of 8-aminoquinolines is also evident from recent reports. For example, primaquine has been found to inhibit mitogen induced human lymphocyte proliferative response and in therapeutic doses it has shown immunosuppressant activity [128]. However, it is not clear whether patients receiving primaquine are immunosuppressed [129]. Primaquine exhibits antimuscarinic effect on the guinea-pig bladder and on gastrointestinal tract motility, as evident from the transport of charcoal meal. Thus, primaquine behaves as an antagonist of acetylcholine [130]. Pamaquine treatment of cattle infected with Thuleria sergenti has been found to cause a moderate increase in the clotting time, decrease in platelet adhesiveness and change in the thromboelastogram [131]. At low concentration, primaquine produces transient positive chronotropic and ionotropic effects in isolated guinea-pig heart, but shows negative chronotropic and ionotropic effects at higher doses [132].

Recent investigations relate to the understanding of biochemical processes leading to 8-aminoquinoline induced haemolytic anaemia. It is generally believed that the haemolytic anaemia may arise either because of a deficiency of enzymes of the metabolic system that protect the cell against the stress of an oxidant [133], or because of the susceptibility of molecular variants of haemoglobin to the stress [134]. The nature and mechanism of oxidant stress in red cells has, therefore, become a subject of detailed investigation. The roles of reduced and oxidized forms of NADP and glutathione and the detoxification pathway of $\mathrm{H}_{2} \mathrm{O}_{2}$ and oxygen radicals, which are presumed to be toxic to the red cells, have been studied [120]. Glutathione reductase and glutathione peroxidase form an integrated system with $\mathrm{G}_{6} \mathrm{PD}$ and 6-phosphonic gluconic dehydrogenase for the protection of the cell against oxidant stress. It has been observed that glutathione peroxidase detoxifies $\mathrm{H}_{2} \mathrm{O}_{2}$, which would partly explain the mechanism of resistance of normal cells to stress [120]. The effect of primaquine on the metabolism of normal, $\mathrm{G}_{6} \mathrm{PD}$ deficient and glutathione reductase deficient cells has been studied by examining the effect of drug on the ability of human red cells to increase the oxidation of $1-^{14} \mathrm{C}$ glucose [120]. Prima- 
quine stimulates the oxidative pathway of glucose metabolism in normal human erythrocytes, as measured by ${ }^{14} \mathrm{CO}_{2}$ production but fails to stimulate glucose metabolism in $\mathrm{G}_{6} \mathrm{PD}$ deficient cells. Production of ${ }^{14} \mathrm{CO}_{2}$ induced by primaquine is markedly diminished in glutathione deficient cells [120]. It is interesting to note that 6-methoxy-8-aminoquinoline, the skeletal framework of primaquine, at same molar concentrations causes twice the production of ${ }^{14} \mathrm{CO}_{2}$ compared to primaquine and is also twice as active as primaquine in stimulating ${ }^{14} \mathrm{CO}_{2}$ production in glutathione reductase deficient cells [120]. It has been observed that primaquine exhibits increased production of ${ }^{14} \mathrm{CO}_{2}$ in red cells 24 hours after injection of drug, but the nature of the stimulating factor has not yet been established. Nevertheless, the haemolysis induced by primaquine, may be due to the failure of one of the steps in the oxidative metabolism of glucose to detoxify $\mathrm{H}_{2} \mathrm{O}_{2}$ and/or other oxidants [120].

\section{$4.3 \quad$ Toxicity}

The knowledge of the toxic effects of 8 -aminoquinolines is based on the studies carried out with 858 -aminoquinolines in rhesus monkeys [135]. Two types of toxic reactions have been identified and correlated with the length of side chain attached to position 8 of the quinoline ring. Compounds in which the secondary and tertiary amino groups are separated from the 8-amino nitrogen by a chain of 2-3 methylene groups exhibit irreversible neurotoxicity selectively for brain stem nuclei [136]. Electron microscopic studies indicate the degeneration of neuronal mitochondria in large multipolar neurons [137]. Compounds having more than four methylene groups, exhibit reversible hepatotoxicity and gastrointestinal and haematological disorders [120] because of its lower toxicity compared to pamaquine and other 8-aminoquinolines, primaquine has been preferred for conducting clinical studies. The clinial course of haemolysis induced with a daily dosage of $30 \mathrm{mg}$ of primaquine in primaquine sensitive healthy Negro males shows an acute haemolytic phase on administration of the drug [138-140]; $30-40 \%$ of the red cells are destroyed, serum bilirubin is raised to 3-5 $\mathrm{mg} \%$ and in many cases jaundice has been noticed. However, if the treatment is allowed to continue, destruction of erythrocytes stops possibly because only the older erythrocytes are destroyed. Clinical recovery starts on the 10th-12th day of treatment and haemoglobin level 
becomes normal in 4-5 weeks. Despite continued drug administration, normal haemoglobin level is maintained which can be explained on the basis that new erythrocytes are more resistant to further haemolysis by primaquine. Besides African subjects, toxicity of primaquine in $\mathrm{G}_{6}$ PD deficient individuals from Iran, Burma, Thailand, Sri Lanka and Arab countries has been reported [141-144].

Recent studies on the toxicity of primaquine relate to the change form of drug administration [145]. Interest in this area arose because of two reasons. Firstly, no 8-aminoquinoline better than primaquine was known when the studies were initiated and secondly, no other class of compounds, except 8-aminoquinolines, had emerged as effective tissue schizontocidal agent. The concept of modified forms of administration of a drug is aimed at reducing its toxicity. Two main approaches can be identified. One is concerned with making complexes of primaquine with a carrier molecule [145], such that the complexes are recognized and selectively taken up by the hepatocytes and are not cleaved in the blood stream to release the drug. A different approach is based on synthesis of a prodrug by appropriate functionalization of the terminal amino group of the primaquine side chain. The prodrug should be stable in the blood stream and be sequestered by the liver alone. It may then be expected to selectively deliver primaquine to the liver. The biodegradable appendage of the prodrug should be non toxic. Since liposomes are preferentially captured by liver and spleen, primaquine entrapped in liposomes has been subjected to toxicity studies. Primaquine when incorporated in liposomes and administered intravenously is 3.5 times less toxic than the parent drug. The maximum tolerated dose of primaquine base in mice has been reported to be 14 $\mathrm{mg} / \mathrm{kg}$ compared to the $60 \mathrm{mg} / \mathrm{kg}$ of primaquine entrapped in liposomes. Similarly, the $\mathrm{LD}_{50}$ of primaquine is $22 \mathrm{mg} / \mathrm{kg}$ and that of entrapped primaquine in liposomes $79 \mathrm{mg} / \mathrm{kg}$ [145]. Pharmacokinetic studies of primaquine entrapped in liposomes indicate $45 \%$ elimina-

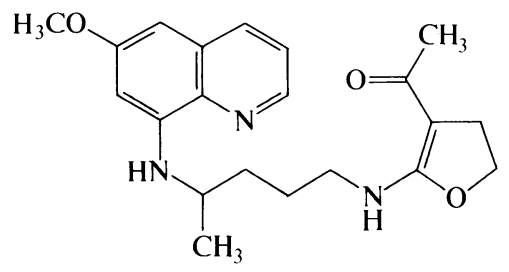


tion of the drug 1 minute after injection. The distribution of primaquine in tissues after administration of primaquine entrapped in liposomes is very different than that of the water soluble salt of primaquine. The concentration of primaquine expressed as $\mathrm{nm} / \mathrm{gm}$ of tissue protein is the highest in spleen $(1,900)$ and is followed by liver $(900)$, and other tissues (less than 300). Compared to this, the distribution of free primaquine in the biophase is: lungs, 3,700 and liver and spleen, 600 [145]. Two types of chemical modifications have been carried out to obtain a possible prodrug of primaquine. In the first approach a small peptide unit has been covalently linked with the terminal amino group of the side chain [87]. The amino acid and the peptide units used for this purpose are L-leucine, N-L-alanyl-L-leucine and N-L-alanyl-L-leucyl-L-alanyl-L-leucine. The $\mathbf{L}$-leucine conjugates of primaquine (leu-PQ), ala-leu-PQ and ala-leuala-leu-PQ are hydrolyzed by lysosomal enzymes to release free primaquine. However, leu-PQ is not hydrolyzed in presence of serum while the other two derivatives are hydrolyzed to release leu-PQ. The MTD values of leu-PQ, ala-leu-PQ and ala-leu-ala-leu-PQ are 22 and $29 \mathrm{mg} / \mathrm{kg}$, respectively. Similarly, the $\mathrm{LD}_{50}$ values of these three derivatives have been recorded as 27 and $41 \mathrm{mg} / \mathrm{kg}$, respectively. In the second approach, a cyclic enaminone of primaquine (LXXXI) has been synthesized as a prodrug of primaquine and found to exhibit radical curative activity in rhesus monkey against $P$. cynomolgi infection $[101,146]$. The maximum tolerated dose of this compound is $450 \mathrm{mg} / \mathrm{kg}$, i. p. mice [101]. In yet another approach, which is completely different from the two approaches discussed earlier, an attempt has been made to reduce the toxicity of racemic primaquine by resolving it into its optical antipodes [147]. It has been observed that whereas the curative activities of individual optical antipodes and of the racemate, in rhesus monkeys against $P$. cynomolgi infection are almost identical, 1-primaquine is 3-5 times as toxic as $d$-primaquine and at least twice as toxic as racemic primaquine. It has, therefore, been suggested on the basis of total dose required to evoke fatal reactions that a critical comparison of toxicities of $d$-primaquine and racemic primaquine in human volunteers is necessary. 


\subsection{Miscellaneous studies}

Resistance to primaquine in experimental infections in human volunteers has been demonstrated by Arnold et al. [18] by 36 sequential passages during 250 days of continuous drug selection pressure. Field reports regarding treatment with primaquine $[18,150,151]$ in Vietnam and other places do not mention any serious problems. Sensitive analytical tools for detecting metabolites of 8-aminoquinolines have been developed in recent years. These include thin layer chromatography, gas liquid chromatography in conjunction with radioactive monitoring techniques and mass spectrometric analysis including field desorption mass spectrometry [101]. Besides 8-aminoquinolines, 6 - and 7-aminoquinolines have also been studied recently as causal prophylactic, blood schizontocidal and tissue schizontocidal agents [152].

5

Conclusions

Malaria is recognized as one of the major world health problems on account of its remarkable global incidence due to the mobility of human population and because of the number of cases imported into countries of the temperate zone. The absence of any immediate prospects of a malaria vaccine, emergence of drug-resistance in P. falciparum infection and the limited armamentarium of causal prophylactics and radical curative drugs have made the global eradication of malaria, a hope in the extremely distant future. Although the chemotherapy of $P$. falciparum infection has attracted maximum attention, the need for developing causal prophylactics and radical curative agents against $P$. vivax infection has not been ignored by the World Health Organization. Current research activities have raised many questions, a few of which have been answered while the rest have yet to be resolved. An analysis of the present status of knowledge of $P$. vivax infection would reveal the problems that are of immediate interest for malarial chemotherapy.

The enormous amount of data generated regarding structure-activity relationship (SAR) in 8-aminoquinolines are primarily based on their blood schizontocidal activity in experimental models. The available SAR data on tissue schizontocidal activity are meagre and very little attempt has been made to understand the exact role of the side chain of primaquine and other tissue schizontocidal agents. Despite the fact 
that pharmacokinetic studies of primaquine have indicated sequestering of the drug by the liver in the biophase, an understanding of the structural parameters of the side chain, necessary for getting sequestered by the liver awaits more experimental data. Addition to knowledge in this area would immensely help in the design of new tissue schizontocides. Studies on the role of the side chain in enzyme 8 -aminoquinoline metabolite(s) interactions may be very fruitful because primaquine and other 8 -aminoquinolines are known to produce their antimalarial effect by interfering with the dihydroorotate dehydrogenase enzyme system in the parasite through their redox active metabolites. The significant difference in the toxicities of $d$ - and $l$-primaquine suggests the need for studying the difference, if any, in their sequestration by the liver. It is surprising that even the most recent pharmacokinetic studies have not been able to establish the immediate fate of sequestered primaquine in liver. It would also be interesting if the rate of sequestering of 8 -aminoquinolines is ascertained in both infected and normal livers. The half-life of primaquine, the distribution of its optical antipodes in liver, the identification of the hepatic enzyme(s) involved in the envisaged N-C cleavage of the side chain attached to position 8 of the quinoline ring, the distribution of the metabolite(s) in liver and the exact mechanism by which the metabolite(s) exert their tissue schizontocidal effect in experimental animals are of great interest for designing less toxic derivatives of primaquine. It is likely that the sequestering effect and metabolism by the liver are different in humans and in experimental animals. The problem associated with SAR studies is the non-availability of information about the contribution of the quinoline or polysubstituted quinoline ring per se to the generation of redox active metabolites in the liver. The understanding of the toxicity profile of these metabolites is also important for designing tissue schizontocidal agents with better therapeutic index. A good experimental model is required for studying side effects of possible 8-aminoquinoline antimalarials and their metabolites in case of glucose-6-phosphate dehydrogenase deficiency. The understanding of the state of parasitaemia at doses lower than the radical curative dose in experimental animals may possibly help in the design of slow-releasing preparations of 8-aminoquinoline derivatives.

Besides these, another obvious lacuna in present knowledge is regarding the exact number of metabolites of primaquine produced in humans and experimental animals. The mechanism by which the metab- 
olites are produced and localized at their sites of action is also not very clear. Studies in these directions are essential in view of the observation that peptide derivatives of primaquine are less toxic than primaquine diphosphate. While these observations have evoked interest in the synthesis of prodrugs of primaquine, the knowledge of pharmacophores essential for generating a prodrug is far from satisfactory. While the clinical use of tissue schizontocides entrapped in liposomes appears to have a future, there is also a need for evaluating 6-methoxy8 -aminoquinoline as a tissue schizontocidal agent after its delivery into the liver has been ensured. This would help to ascertain whether the side chain of primaquine is essential only for sequestration of the drug by the liver or it is also required for enzyme recognition prior to metabolism. In this context it is essential to point out that the hepatic distribution of 8-aminoquinoline antimalarials and/or their metabolites should be studied in greater detail. The various problems which require immediate attention are summarized in the figures.

Finally, it may be concluded that the development of an acceptable 8aminoquinoline antimalarial, better than primaquine, may be realized in the not too distant future.

\section{Acknowledgment}

Thanks are due to Dr. S. Bhattacharya for rendering all possible help in the preparation of the manuscript.

\section{References}

1 R. H. Black, C. J. Canfield, D. F. Clyde, W. Peters and W. H. Wernsdorfer: Chemotherapy of Malaria. World Health Organization Monograph Series No. 27, World Health Organization, Geneva 1981.

2 Wld Hlth Org. techn. Rep. Ser. 296(1961).

3 Wld Hlth Org. techn. Rep. Ser. 467(1971).

4 T. Lepes: Bull. Wld Hlth Org. 50, 151 (1974).

5 K. H. Rieckmann, J. V. McNamara, H. Frischer, T. A. Stockert, P. E. Carson and R. D. Powell: Am. J. trop. Med. Hyg. 17, 661 (1968).

6 K. H. Rieckmann: J. Am. med. Ass. 217, 573 (1971).

7 P. C. C. Garnham, R. S. Bray, L. J. Bruce-chwatt, C. C. Draper, R. K. Kendrick, P. G. Sergiev, N. A. Tiburskaja, P. G. Shute and M. Maryon: Bull. Wld Hlth Org. 52, 21 (1975).

8 A. J. Lysenko, A. E. Beljaev and V. M. Rybalka: Bull. Wld Hlth Org. 55, 541 (1977).

9 W. H. Wernsdorfer: Bull. Wld Hlth Org. 55, 133 (1977).

10 E. Fink: Bull. Wld Hlth Org. 50, 213 (1974).

11 R. C. Elderfield: Chem. Eng. News 24, 2598 (1946).

12 R. F. Loeb: J. Am. med. Ass. 132, 321 (1946). 
13 A. S. Alving, J. Arnold and D. H. Robinson: J. Am. med. Ass. 149, 1558 (1952).

14 W. C. Cooper, A. V. Myatt, T. Hernandez, G. M. Jeffery and G. R. Coatney: Am. J. trop. Med. Hyg. 2, 949 (1953).

15 J. H. Edgcomb, J. Arnold, E. H. Yount, Jr., A. S. Alving and L. Eichelberger: J. natn. malar. Soc. 9, 285 (1950).

16 A. S. Alving, C. F. Johnson, A. R. Tarlov, G. J. Brewer, R. W. Kellermeyer and P. E. Carson: Bull. Wld Hlth Org. 22, 621 (1960).

17 R. H. Black: Aust. Ann. Med. 1, 259 (1958).

18 J. Arnold, A. S. Alving, C. B. Clayman and R. S. Hochwald: Trans. R. Soc. trop. Med. Hyg. 55, 345 (1961).

19 D. S. Rane and K. E. Kinnamon: Am. J. trop. Med. Hyg. 28, 937 (1979).

20 T. S. Osdene, P. B. Russell and L. Rane: J. med. Chem. 10, 431 (1967).

21 K. G. Gregory and W. Peters: Ann. trop. Med. Parasit. 65, 15 (1970).

22 J. Hill: Ann. trop. Med. Parasit. 69, 421 (1975).

23 D. C. Warhurst and R. O. Folwell: Ann. trop. Med. Parasit. 62, 349 (1968).

24 H. Most and W. A. Montouri: Am. J. trop. Med. Hyg. 24, 179 (1975).

25 L. H. Schmidt, R. N. Rossan and K. F. Fisher: Am. J. trop. Med. Hyg. 12, 494 (1963).

26 O. Y. Magidson and I. T. Strukov: Arch. Pharm. 271, 569 (1933).

27 O. Y. Magidson, O. S. Madaeva and M. V. Rubzov: Arch. Pharm. 273, 320 (1935).

28 O. Y. Magidson, N. M. Delektorskaya and I. M. Lipovich: Arch. Pharm. 272,74(1934).

29 A. W. Baldwin and R. Robinson: J. chem. Soc., p. 1264 (1934).

30 W. Meisel and R. Robinson: J. chem. Soc., p. 1267 (1934).

31 R. Robinson and M. L. Tomlinson: J. chem. Soc., p. 1524 (1934).

32 W. L. Glen and R. Robinson: J. chem. Soc., p. 557 (1943).

33 J. Gum and R. Robinson: J. chem. Soc., p. 561 (1943).

34 O. Y. Magidson and M. D. Bobyshev: J. gen. Chem. USSR 8, 889 (1938).

35 W. Huber, R. K. Bair, W. Bochme, S. C. Laskowski, M. Jackman and R. O. Clinton: J. Am. chem. Soc. 61, 1849 (1945).

36 R. C. Elderfield, W. J. Gensler, J. D. Head, H. A. Hageman, C. B. Kremer, J. B. Wright, A. D. Holley, B. Williamson, J. Galbreth, L. Weiderhold III, R. Froherdt, S. Kupchan, T. A. Williamson and O. Birstein: J. Am. chem. Soc. $68,1524(1946)$.

37 H. Gilman and L. A. Woods: J. Am. chem. Soc. 67, 1843 (1945).

38 G. W. Moersch, R. W. Gouley, H. T. Patricson and H. S. Mosher: J. Am. chem. Soc. 69, 2619 (1947).

39 R. C. Elderfield, C. B. Kremer, S. M. Kupchen, O. Bristein and G. Cortes: J. Am. chem. Soc. 69, 1258 (1947).

40 N. L. Drake, R. A. Hayes, J. A. Garman, R. B. Johnson, G. W. Kelley, S. Melamed and R. M. Peck: J. Am. chem. Soc. 71, 455(1949).

41 N. L. Drake and J. A. Garman: J. Am. chem. Soc. 71, 2425 (1949).

42 R. C. Elderfield, E. F. Claftin, H. E. Mertel, O. L. McCurdy, R. T. Mitch, C. D. Ver Nooy, B. H. Wark and I. M. Wempen: J. Am. chem. Soc. 77, 4819 (1955).

43 C. R. Hauser, M. S. Bloom, D. S. Breslow, J. T. Adams, S. T. Amore and M. J. Weiss: J. Am. chem. Soc. 68, 1544 (1946).

44 T. R. Norton, R. A. Seibert, A. A. Benson and F. W. Bergstrom: J. Am. chem. Soc. 68, 1572 (1946).

45 W. M. Lauer, R. T. Arnold, B. Tiffenny and C. O. Wilson: J. Am. chem. Soc. $68,1548(1946)$.

46 W. M. Lauer, C. Rondestvedt, R. T. Arnold, N. L. Drake, J. V. Hook and J. Tinker: J. Am. chem. Soc. 68, 1546 (1946).

47 K. Matejka and R. Robinson: J. Am. chem. Soc., p. 1322 (1934). 
48 M. Carmack, L. W. Kissinger and I. Von: J. Am. chem. Soc. 68, 1551 (1946).

49 W. C. Cooper, A. V. Myatt, T. Hernandez, G. M. Jeffery and G. R. Coatney: Am. J. trop. Med. Hyg. 2, 949 (1953).

50 K. N. Campbell, R. A. LaForge and B. K. Campbell: J. org. Chem. 14, 346 (1949).

51 S. M. Talati, M. R. Latham, E. G. Moore, G. W. Hargreaves and C. D. Blanton, Jr.: J. pharm. Sci. 59, 491 (1970).

52 L. H. Schmidt and C. S. Genther: J. Pharmac. exp. Ther. 107, 61 (1953).

53 R. V. Shetty and C. DeWitt Blanton, Jr.: J. med. Chem. 21, 995 (1978).

54 R. V. Shetty, W. P. Wetter and C. DeWitt Blanton, Jr.: J. med. Chem. 20, 1349 (1977).

55 P. E. Thompson and L. M. Werbel: Antimalarial agents - Chemistry and Pharmacology, p. 100-118. Ed. G.D. Stevens, Academic Press, New York 1972).

56 F. I. Carroll, B. D. Berrang and C. P. Linn: J. med. Chem. 22, 1363 (1979).

57 F. I. Carroll, B. D. Berrang, C. P. Linn and C. E. Twine, Jr.: J. med. Chem. 22, 694(1979).

58 W. Peters, E. E. Davies and B. L. Robinson: Ann. trop. Med. Parasit. 69, 311 (1975).

59 L. H. Schmidt: Annu. Rev. Microbiol. 23, 427 (1969).

60 M. P. LaMontagne, A. Markovac and J. R. Menke: J. med. Chem. 20, 1122 (1977).

61 K. E. Kinnamon and D. S. Rane: Am. J. trop. Med. Hyg., in preparation (vide ref. 56).

62 W. P. Wetter and C. DeWitt Blanton, Jr.: J. med. Chem. 17, 620 (1974).

63 W. Peters: Exp. Parasit. 17, 80 (1965).

64 K. Tanabe, E. H. Chen, B. L. Verma, A. J. Saggiomo and E. A. Nodiff: J. med. Chem. 21, 133 (1978).

65 E. H. Chen, A. J. Saggiomo, K. Tanabe, B. L. Verma and E. A. Nodiff: J. med. Chem. 20,1107(1977).

66 E. A. Nodiff, K. Tanabe, E. H. Chen and A. J. Saggiomo: J. med. Chem. 25, 1097 (1982).

67 M. P. LaMontagne, A. Markovac and M. S. Khan: J. med. Chem. 25, 965 (1982).

68 M. P. LaMontagne, P. Blumbergs and R. E. Strube: J. med. Chem. 25, 1094 (1982).

69 L. H. Schmidt, R. N. Rossan, R. Fradkin and J. Woods: Bull. Wld Hlth Org. 34, 783 (1966).

70 F. I. Carroll, J. T. Blackwell, A. Philip and C. E. Twine: J. med. Chem. 19, $1111(1976)$.

71 S. Archer, P. O. Gyimah and S. Silbering: J. med. Chem. 23, 517 (1980).

72 J. P. Scovill, D. L. Klayman, T. S. Woods and T. R. Sweeney: J. med. Chem. 22, 1164(1979).

73 F. C. Lefler, H. S. Lilja and D. J. Holbrook, Jr.: Biochem. Pharmac. 22, 715 (1973).

74 I. W. Sherman and L. Tanigoshi: Proc. helminth. Soc., Wash., 39, 250 (1972).

75 F. C. Lefler: Diss. Abstr. Int. (B). 33, 1383 (1972).

76 R. Roskoski, Jr., and S. R. Jaskanas: Biochem. Pharmac. 21, 391 (1972).

77 K. A. Conklin and S. C. Chou: Science, N. Y. 170, $1213(1970)$.

78 J. R. Burdick and D. P. Durand: Antimicrob. Ag. Chemother. 6, 460 (1974).

79 J. G. Olenick and F. E. Hahan: Antimicrob. Ag. Chemother. 1, 259 (1972).

80 B. Wittels: Biochem. Pharmac. 20, 2099(1971).

81 H. Y. Pan, S. C. Chou and K. A. Conklin: Pharmacology 12, 48 (1974).

82 K. A. Conklin, P. Heu and S. C. Chou: Molec. Pharmac. 9, 304 (1973).

83 G. Carter and K. Van Dyke: Proc. helminth. Soc., Wash. 39, 244 (1972). 
84 C. H. Lantz and K. Van Dyke: Exp. Parasit. 31, 255 (1972).

85 D. J. Holbrook, L. P. Wichard, C. R. Morris and L. A. White: Prog. molec. Subcell. Biol. 2, 113 (1971).

86 K. A. Conklin and S. C. Chou: J. Pharmac. exp. Ther. 180, 158 (1972).

87 R. C. Field, B. R. Gibson, D. J. Holbrook, Jr., and B. M. Maccall: Br. J. Pharmac. 62, 159 (1978).

88 L. P. Wichard, M. E. Washington and D. J. Holbrook, Jr.: Biochim. biophys. Acta 287, 52 (1972).

89 K. A. Conklin, S. C. Chou and P. Heu: Biochem. Pharmac. 20, 1877 (1971).

90 M. Brunori, E. Fioretti and G. Ritilio: Molec. cell. Biol. 19, 43 (1978).

91 S. N. Kelman, S. G. Sullivan and A. Stern: Biochem. Pharmac. 30, 81 (1981).

92 P. J. Sides and B. Wittes: Biochem. Pharmac. 24, 1246 (1975).

93 T. K. Li and L. J. Magnes: Biochem. Pharmac. 21, 17 (1972).

94 L. H. Schmidt: A Survey of Antimalarial drugs, p. 106-129. Ed. J. W. Edwards: Ann Arbor, Mich., 1946.

95 T. J. Kennedy: Fed. Proc. 5, 185 (1946).

96 C. G. Zubrod, T. J. Kennedy and J. A. Shannon: J. clin. Invest. 27, 114 (1948).

97 A. S. Alving, B. Craige, Jr., R. Jones, Jr., C. M. Whorton, T. N. Pullman and L. Eichelberger: J. clin. Invest. 27, 25 (1948).

98 R. W. Berliner, D. P. Earle, Jr., J. V. Taggart, W. J. Welch, C. G. Zubrod, P. Knowlton, J. A. Atchley and J. A. Shannon: J. clin. Invest. 27, 108 (1948).

99 F. Y. Wiselogle: A Survey of Antimalarial drugs, 1941-1945, 2 vols. Ed. J. W. Edwards: Ann Arbor, Mich., 1946.

100 K. A. Flecher, D. A. P. Evans, H. M. Gilles, J. Greaves, D. Bunnag and T. Harinasuta: Bull. Wld Hlth Org. 59, 407 (1981).

101 B. Bhat: Ph. D. Thesis, Division of Medicinal Chemistry, Central Drug Research Institute, Lucknow 1983.

102 D. J. Holbrook, C. C. Collins and A. M. Clark: J. pharm. Sci. 68, 1239 (1981).

103 C. C. Smith: J. Pharm. exp. Ther. 116, 67 (1956).

104 B. Brodie and S. Underfriend: Proc. Soc. exp. Biol. Med. 74, 845 (1950).

105 J. D. Bety, D. A. P. Evans and P. A. Robinson: Biomed. mass spectrom. 2, 304 (1975).

106 A. Strother, I. M. Fraser, R. K. Allahyari and B. C. Tilton: Bull. Wld Hith Org. 59, 413(1981).

107 C. D. Hufford, M. A. Clark, I. N. Quinones, J. K. Baker and D. J. McChesney: J. pharm. Sci. 72, 92 (1983).

108 J. Greenberg, D. J. Taylor and E. S. Josephson: J. infect. Dis. 88, 163 (1951).

109 W. E. Gutteridge and G. H. Coombs: Biochemistry of Parasitic Protozoa. Macmillan, London 1977.

110 R. S. Krooth, K. D. Wuu and R. Ma: Science, N. Y. 164, 1073 (1969).

111 W. E. Gutteridge, D. Dave and W. H. G. Richards: Biochim. biophys. Acta $582,390(1979)$.

112 C. H. Lantz and K. Vandyke: Fed. Proc. 29, 808 (1970).

113 C. R. Morris, L. V. Andrew, L. P. Wichard and D. J. Hoolbrook: Molec. Pharmac. 6, 240 (1970).

114 M. E. Washington, L. A. White and D. J. Holbrook, Jr.: Biochem. Pharmac. 22, 477 (1973).

115 C. B. Clayman, J. Arnold, R. S. Hockwald, E. J. Yount, Jr., J. H. Edgcomb and A. S. Alving: J. Am. med. Ass. 149, 1563 (1952).

116 C. G. Zubrod: Fed. Proc. 5, 217 (1946).

117 F. Sioli: Arch. Schiffs- u. Tropenhyg. 30,319(1926).

118 G. J. Brewer, A. R. Tarlov, R. W. Kellermeyer and A. S. Alving: J. Lab. clin. Med. 59, 905(1962). 
119 R. S. Grewal: Bull.Wld Hlth Org. 59, 397 (1981).

120 P. E. Carson, R. Hohl, M. V. Nora, G. W. Parkhurst, T. Ahmad, S. Scanlan and H. Frischer: Bull. Wld Hlth Org. 59, 427 (1981).

121 F. L. Ginn, P. Hochstein and B. F. Trump: Science, N. Y. 164, 843 (1969).

122 A. R. Tarlov, G. J. Brewer, P. E. Carson and A. S. Alving: Arch. int. Med. 109, 209 (1962).

123 E. Bentler and M. Mitchell: Blood 32, 816(1969).

124 A. P. Richardson, H. A. Walker and B. S. Miller: Proc. Soc. exp. Biol. Med. 65, 258 (1947).

125 G. K. Moe, B. Peralta and M. H. Seevers: J. Pharmac. exp. Ther. 95, 407 (1949).

126 R. B. Arora and B. R. Madan: Arch. int. Pharmacodyn. Ther. 107, 215 (1956).

127 E. L. Holland and R. S. McCutcheon: J. pharm. Sci. 51, 791 (1962).

128 Y. H. Thong, A. Ferrante and B. R. Kelley: Trans. R. Soc. trop. Med. Hyg. 72,537 (1978).

129 Y. H. Thong: Trans. R. Soc. trop. Med. Hyg. 73, 474(1979).

130 E. R. Seidel, R. L. Mundy and R. S. Teague: Toxic. appl. Pharmac. 45, 258 (1978).

131 Y. Hayashi: Bull. Fac. Agr., Tottori University 30, 82 (1979).

132 R. J. Marshall and J. A. O. Ojewoli: Toxic. appl. Pharmac. 46, 759 (1978).

133 P. E. Carson and H. Frischer: Am. J. Med. 41, 744 (1966).

134 H. Lehmann and P. A. M. Kynoch: Human haemoglobin variants and their characteristics. Amsterdam, New York, Oxford, North Holland 1976.

135 L. H. Schmidt: Fed. Proc. 6, 368 (1947).

136 I. G. Schmidt and L. H. Schmidt: J. Neuropath. exp. Neurol. 7, 368 (1949).

137 J. C. Sipe, A. V. Nicholas, S. Sidney and F. Cesar: J. Neuropath. exp. Neurol. 32, 446 (1973).

138 R. J. Dern, E. Beutler and A. S. Alving: J. Lab. clin. Med. 44, 171 (1954).

139 R. W. Kellermeyer, A. R. Tarlov, S. L. Schrier, P. E. Carson and A. S. Alving: J. Lab. clin. Med. 58, 225 (1961).

140 A. R. Tarlov, G. J. Brewer, P. E. Carson and A. S. Alving, Arch. intern. Med. 109, 209 (1962).

141 M. Ziai, G. H. Amirhakami, J. G. Reinhold, M. Tabatabee, M. E. Gettner and J. E. Bowman: Clin. Pediat. 6, 242 (1967).

142 S. A. Chopra: E. Afr. med. J. 45, 726 (1968).

143 A. T. Batu, U. H. Pe and T. Than: Trans. R. Soc. trop. Med. Hyg. 64, 785 (1970).

144 K. P. Abeyaratne and N. L. Halpe: Ceylon Med. J. 27, 134 (1968).

145 A. Trouet, P. Pirson, R. Steiger, M. Masquelier, R. Baurain and J. Gillet: Bull. Wld Hlth Org. 59, 449 (1981).

146 G. P. Dutta: Personal communication (Division of Microbiology, Central Drug Research Institute, Lucknow, India).

147 L. H. Schmidt, S. Alexander, L. Allen and J. Rosco: Antimicrob. Ag. Chemother. 12, 51 (1977).

148 F. S. Skeleton, P. J. Reitz and K. Folkers: J. med. Chem. 13, 602 (1970).

149 F. S. Skeleton, R. S. Pardini, J. C. Heidker and K. Folkers: J. Am. chem. Soc. 90, 334(1968).

150 L. D. Heaton: Milit. Med. 128,6(1963).

151 W. Peters: Trans. R. Soc. trop. Med. Hyg. 63, 24(1969).

152 D. E. Davidson, Jr., A. L. AGer, J. L. Brown, F. E. Chapple, B. E. Whitemire and R. N. Rossan: Bull. Wld Hlth Org. 59, 463 (1981). 